\title{
1. ODP LEG 110 AT THE NORTHERN BARBADOS RIDGE: INTRODUCTION AND EXPLANATORY NOTES ${ }^{1}$
}

\author{
Alain Mascle ${ }^{2}$, J. Casey Moore ${ }^{3}$, Elliott Taylor ${ }^{4}$, \\ and \\ Shipboard Scientific Party 5
}

\section{INTRODUCTION}

Convergent plate boundaries constitute one of the most dynamic tectonic environments. There, materials originally formed in the deep ocean are emplaced into an accretionary prism, uplifted, and ultimately exposed as mountain belts. Upon their initial incorporation into accretionary prisms, oceanic sediments typically have more than $50 \%$ porosity whereas, by the time of their subaerial exposure, the accreted rocks normally have less than $10 \%$ porosity. The expulsion of fluid associated with this porosity reduction necessarily causes the development of an active hydrologic system that affects many aspects of the geology. The fluid pressures and movements can not only trigger fault displacements (Hubbert and Rubey, 1959), but control the shape of the accretionary prism (Davis et al., 1983) and transport heat

\footnotetext{
${ }^{1}$ Mascle, A., Moore, J. C., et al., 1988. Proc., Init. Repts. (Pt. A), ODP, 110: College Station, TX (Ocean Drilling Program).

2 Institut Français du Pétrole, 1-4 Ave Boise-Preau, B.P. 311, 92506 Rueil Malmaison Cedex, France.

${ }^{3}$ Dept. of Earth Sciences, University of California at Santa Cruz, Santa Cruz, CA 95064.

4 Ocean Drilling Program, Texas A\&M University, 1000 Discovery Drive, College Station, TX 77840

5 Alain Mascle (Co-Chief Scientist), Institut Français du Pétrole, 1-4 Ave Bois-Preau, B.P. 311, 92506 Rueil Malmaison Cedex, France; J. Casey Moore (Co-Chief Scientist), Dept. of Earth Sciences, University of California at Santa Cruz, Santa Cruz, CA 95064; Elliott Taylor (Staff Scientist), Ocean Drilling Program, Texas A\&M University, College Station, TX 77840; Francis Alvarez, Borehole Research Group, Lamont-Doherty Geological Observatory, Columbia University, Palisades, NY 10964; Patrick Andreieff, BRGM, BP 6009, 45060 Orleans Cedex-2, France; Ross Barnes, Rosario Geoscience Associates, 104 Harbor Lane, Anacortes, WA 98221; Christian Beck, Département des Sciences de la Terre, Université de Lille, 59655 Villeneuve d'Ascq Cedex, France; Jan Behrmann, Institut für Geowissenschaften und Lithosphärenforschung, Universität Giessen, Senckenbergstr. 3, D6300 Giessen, FRG; Gerard Blanc, Laboratoire de Géochimie et Métallogénie U. A. CNRS 196 U.P.M.C. 4 Place Jussieu, 75252 Paris Cedex 05, France; Kevin Brown, Dept. of Geological Sciences, Durham University, South Road, Durham, DH1 3LE, U.K. (current address: Dept, of Earth Sciences, University of California at Santa Cruz, Santa Cruz, CA 95064); Murlene Clark, Dept. of Geology, LSCB 341, University of South Alabama, Mobile, AL 36688; James Dolan, Earth Sciences Board, University of California at Santa Cruz, Santa Cruz, CA 95064; Andrew Fisher, Division of Marine Geology and Geophysics, University of Miami, 4600 Rickenbacker Causeway, Miami, FL 33149; Joris Gieskes, Ocean Research Division A-015, Scripps Institution of Oceanography, La Jolla, CA 92093; Mark Hounslow, Dept. of Geology, Sheffield University, Brook Hill, Sheffield, England S3 7HF; Patrick McLellan, Petro-Canada Resources, PO Box 2844, Calgary, Alberta Canada (current address: Applied Geotechnology Associates, 1-817 3rd Ave. NW, Calgary, Alberta T2N OJ5 Canada); Kate Moran, Atlantic Geoscience Centre, Bedford Institute of Oceanography, Box 1006, Dartmouth, Nova Scotia B2Y 4A2 Canada; Yujiro Ogawa, Dept. of Geology, Faculty of Science, Kyushu University 33, Hakozaki, Fukuoka 812, Japan; Toyosaburo Sakai, Dept. of Geology, Faculty of General Education, Utsunomiya University, 350 Mine-machi, Utsunomiya 321, Japan; Jane Schoonmaker, Hawaii Institute of Geophysics, 2525 Correa Road, Honolulu, HI 96822; Peter J. Vrolijk, Earth Science Board, University of California at Santa Cruz, Santa Cruz, CA 95064; Roy Wilkens, Earth Resources Laboratory, E34-404 Massachusetts Institute of Technology, Cambridge, MA 02139; Colin Williams, Borehole Research Group, Lamont-Doherty Geological Observatory, Columbia University, Palisades, NY 10964.
}

and solutes that have major effects on the diagenesis and metamorphism of deforming rocks. Moreover, the surface expulsion of methane-rich fluids even supports unique benthic communities at convergent margins (Kulm et al., 1986; Le Pichon et al., in press).

ODP Leg 110 was designed to investigate a complex range of geologic and hydrologic problems along the northern Barbados Ridge. The prime technological and scientific objective of Leg 110 was to completely penetrate the accretionary prism, the décollement zone, and underthrust sediment to the oceanic crust. Extensive geophysical surveys and a previous drilling effort on DSDP Leg 78A provided a concrete scientific basis for Leg 110 plans. Here we review the overall regional setting of the northern Barbados Ridge and the results of Leg 78A, explicitly define the goals of Leg 110, and discuss scientific and technological approaches required to achieve these objectives. The explanatory notes provide guidelines for the subsequent Site chapters.

\section{REGIONAL SETTING}

\section{Overview}

The Lesser Antilles volcanic arc is the leading edge of the Caribbean Plate, which has been moving eastward with respect to North and South America since at least Eocene time (Fig. 1). The resulting subduction of the Mesozoic Atlantic oceanic crust beneath the Caribbean is evident seismically to a depth of about $200 \mathrm{~km}$ (Tomblin 1975). The direction and rate of convergence between the Atlantic and Caribbean crusts are not accurately known. From plate-motion models, Jordan (1975) estimated a west-northwest convergence at $2 \mathrm{~cm} / \mathrm{yr}$ in the Leg 110 area whereas Sykes et al (1982) proposed a WSW direction at 3 and 4 $\mathrm{cm} / \mathrm{yr}$ at the same location. Estimates from seismic slip rates are much lower at about 0.25 to $0.5 \mathrm{~cm} /$ year (Dorel, 1981; Molnar and Sykes, 1969).

The Lesser Antilles volcanic arc presently includes eight active volcanoes which have erupted magma that varies in composition from basalts to rhyolites (Westercamp, 1979; Tomblin, 1975). Porphyritic andesites and basaltic andesites are dominant except on the southern islands (Grenada, the Grenadines and St. Vincent) where alkaline basalts occur. Widespread evidence of Neogene volcanism is apparent on the Lesser Antilles islands (Maury and Westercamp, 1985), but the older volcanic rocks have a more restricted distribution: Oligocene lava flows, pyroclastics, and intrusive rocks are known on Antigua island and on the Grenadines; lower to upper Eocene volcanic rocks are exposed on St. Martin, St. Bartholomew, and the Grenadines. This Eocene volcanic activity apparently reflects the initial underthrusting of Atlantic crust beneath an arc of the present geometry. Older volcanic rocks of Upper Cretaceous-Paleocene age dredged on the Aves Ridge, the Upper Jurassic and Lower Cretaceous outcrops on Desirade island, as well as plate kinematics suggest intermittent Mesozoic subduction in the eastern Caribbean (Bouysse, 1984). 


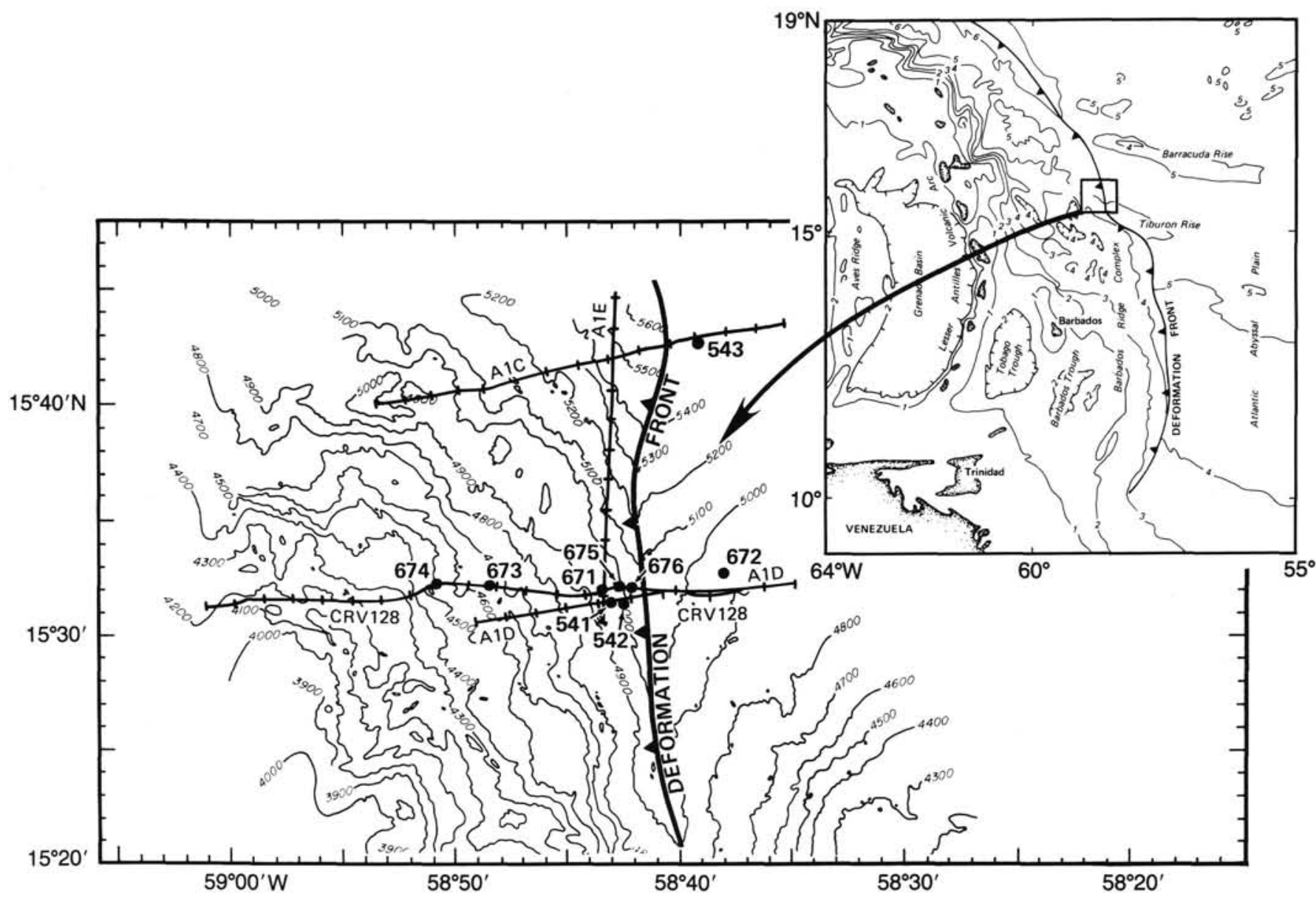

Figure 1. Top-right: Lesser Antilles margin, general location map (contour intervals in kilometers). Bottom-left: Location of ODP Leg 110 Sites 671 through 676 on a Seabeam bathymetric map with location of multichannel seismic profiles and DSDP sites (Contour interval, $100 \mathrm{~m}$ ).

The Grenada Basin (or trough) and the Aves Ridge make up a probable backarc basin and remnant arc, respectively (Figs. 1 and 2). The southern and deeper half of the Grenada Basin is underlain by anomalously thick oceanic crust thought to be of early Tertiary age. The Late Cretaceous-Paleocene ages and the calc-alkaline affinities of rocks dredged from the Aves Ridge, as well as its basement morphology, suggest its original development as a volcanic arc (Pinet, et al., 1985; Boynton, et al., 1979).

The forearc of the Lesser Antilles consists of the Barbados Ridge complex and the Tobago forearc basin (Fig. 2). This forearc narrows from $450 \mathrm{~km}$ in the south to less than $50 \mathrm{~km}$ in the north; the width at the latitude of Leg 110 is about $260 \mathrm{~km}$. The Tobago Basin shows an asymmetrical section on most of the seismic profiles (Fig.3). To the west its sedimentary infilling thins through progressive onlap over the eastward-dipping island arc basement. To the east the thickest portion of the Tobago Basin is being accreted to the Barbados Ridge complex with tight folding and possibly thrusting in pre-Pliocene sediments and moderate folding in the Pliocene to Quaternary sediments.

The Barbados Ridge complex can be divided from east to west in four main zones as shown in Figure 3 (Westbrook, et al., 1984):

\section{Zone of Initial Accretion}

This zone forms the seaward margin of the complex, bounded to the east by the front of deformation. Here sediments of the
Atlantic ocean floor are transferred to the accretionary prism. The style of this initial deformation varies from south to north according to the sediment thickness on the incoming oceanic crust. To the south, thick sedimentary sequences are deformed into broad eastward-verging folds with westward-dipping reverse faults or thrusts occurring at about $5-\mathrm{km}$ intervals as imaged on the seismic records. North of the Tiburon Rise the relatively thin Atlantic sedimentary cover is initially accreted along eastward-verging low-angle thrusts spaced about $1 \mathrm{~km}$ apart. In spite of these disparities between the northern and southern parts of the Barbados Ridge complex, both areas show a clearly developed décollement or detachment surface between the overlying accreted sequences and the underlying underthrust sediments.

\section{Zone of Stabilization}

The zone of stabilization occurs west of the zone of initial accretion and is marked by a decrease in the seaward-dipping slope. The seabottom topography remains rough but rises only gently or may even be flat in the zone of stabilization. This decrease in surface slope probably marks a decrease in the thickening of the wedge (decrease in wedge taper) that may reflect the strengthening of the sediments in an arcward direction (Davis, et al., 1983).

\section{Supracomplex Basins}

This region is restricted to the southern half of the accretionary complex in an area of slightly syntectonically deformed ba- 

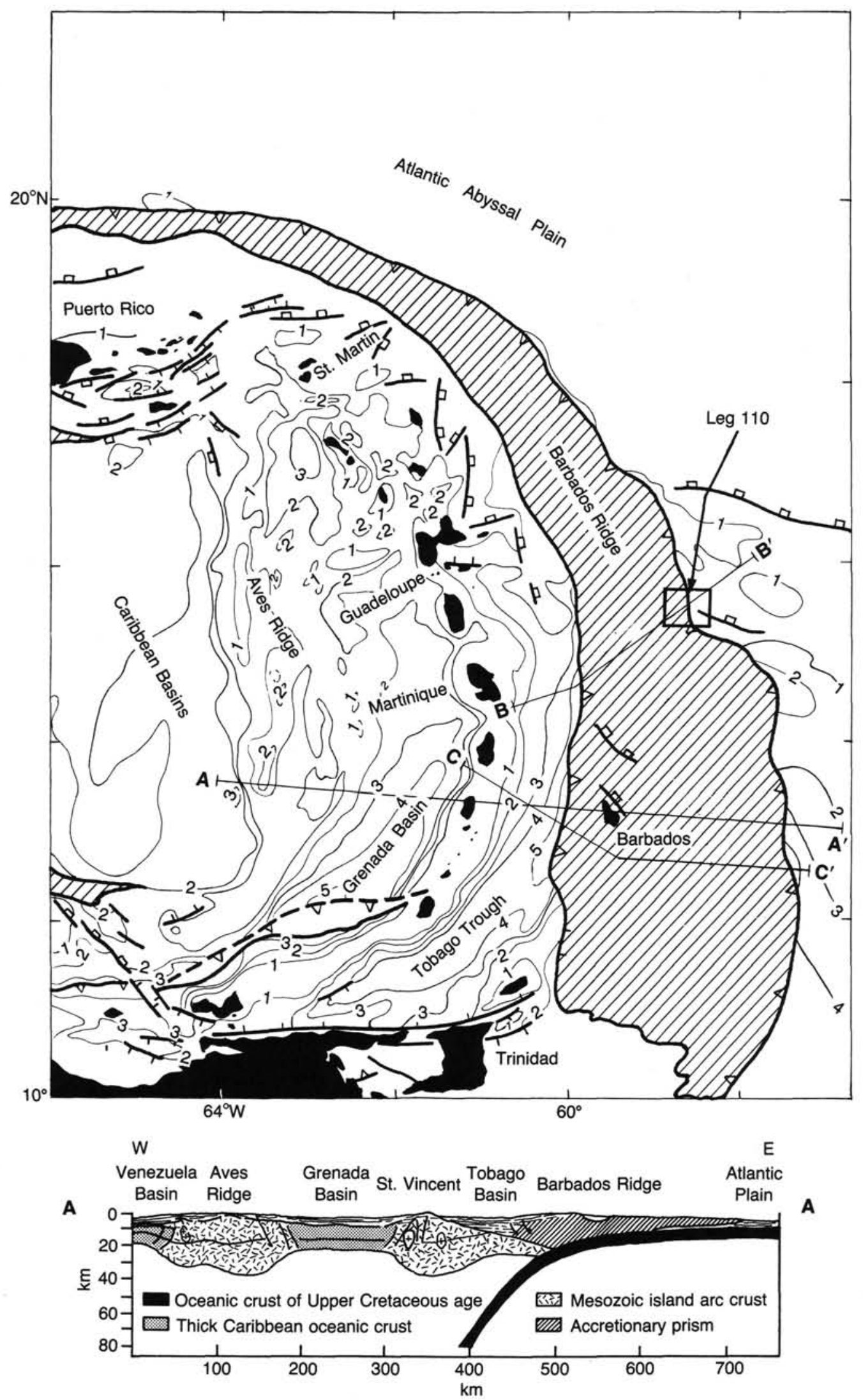

Figure 2. Top: Lesser Antilles margin in the eastern Caribbean geological framework. Contours are isopachs of undeformed sediments (in seconds, two-way traveltime) and dashed areas are accretionary complexes (from Mascle, et al., 1985). Bottom: Cross-sectional model of the Lesser Antilles active margin through Barbados and St. Vincent (from Westbrook, et al., 1984). 

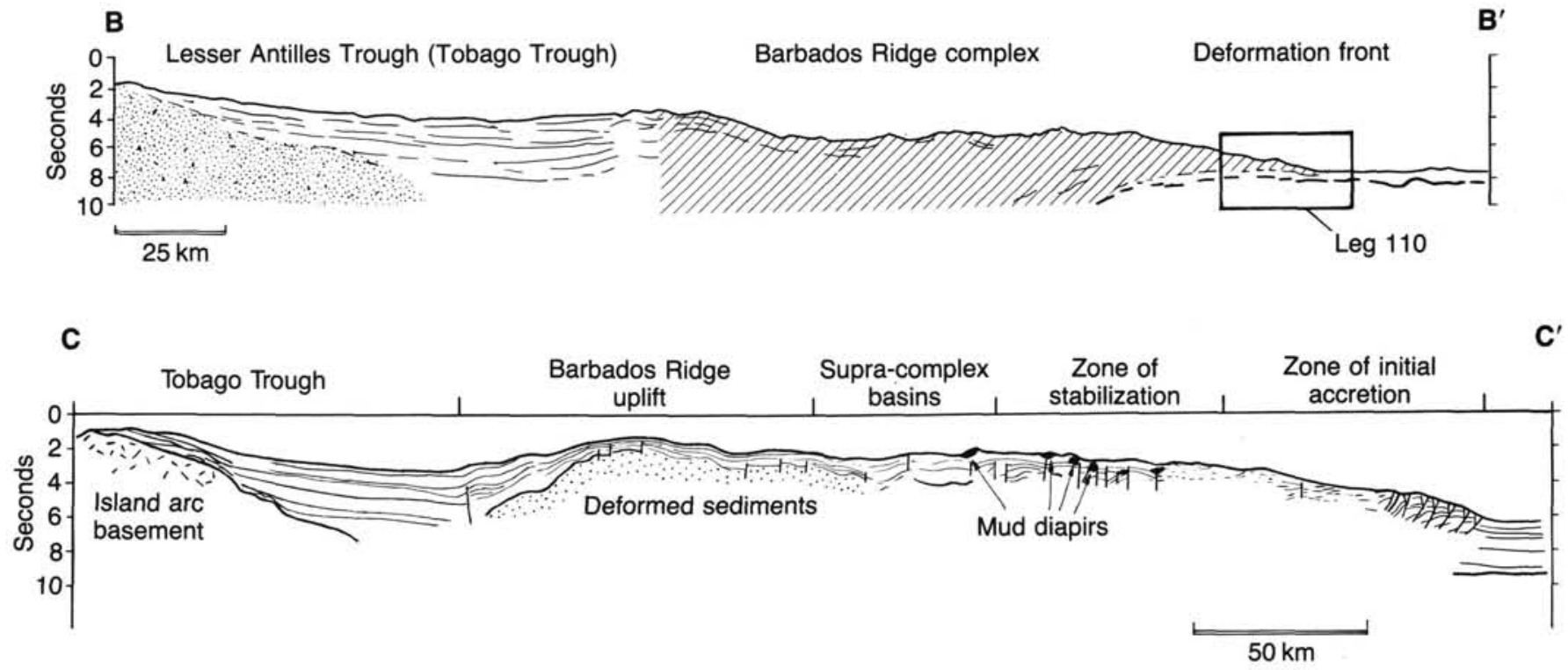

Figure 3. Line-drawings of seismic sections across the Lesser Antilles forearc. Profile locations are shown in Figure 2.

sins. Secondary processes such as gravity sliding and mud diapirism are particularly evident here.

\section{Barbados Ridge Uplift}

This crestal zone of the accretionary complex extends from $15^{\circ} \mathrm{N}$ to $11^{\circ} \mathrm{N}$ only and locally emerges above the sea level at Barbados island. The uplift is as much as $3 \mathrm{~km}$ with respect to the Tobago forearc basin and probably occured in Pliocene and Quaternary time. Barbados island provides an exceptional opportunity to examine the interior of an accretionary prism. Most of the island is covered by a Quaternary limestone (the Coral Reef Formation); however, a small area along the east coast exposes tertiary rocks (Saunders, 1979; Speed, 1981; Biju-Duval, et al., 1985). There, a terrigenous suite of Paleocene to late Eocene age (Scotland Formation) is tightly folded in the east-west direction and subdivided into packets commonly separated by vertical east-west faults. Detailed analysis of sedimentary facies and structures suggests that this terrigenous suite accumulated on the lower slope of a deep sea fan and/or in a trench wedge. The terrigenous suite is overlain structurally, and possibly depositionally, by a few hundred meters of middle Eocene to middle Miocene pelagic rocks (the Oceanic Formation) that may have been accumulated on a trench slope over previously accreted deposits or alternatively in a forearc basin. Both terrigenous and pelagic deposits were folded in middle or late Miocene. Both types of deposits were intruded in the quaternary by large masses of disrupted scaly clays (Joes River Formation) interpreted as the core of a mud diapir.

\section{Setting of the Leg 110 Area}

Leg 110 is located at about $15^{\circ} 30^{\prime} \mathrm{N}$, i.e. at the latitude of Dominica island. There the prominant NW-SE trending Tiburon Rise enters the subduction zone (Fig. 1). The Tiburon Rise dams terrigenous sediments originating from the South American continent, resulting in a thinning of the Atlantic crust sediment cover north of the rise to less than $1000 \mathrm{~m}$. Pelagic and hemipelagic sediments are dominant on the Tiburon Rise in the Leg 110 area. Owing to the lesser volume of sediment input, the width of the accretionary complex is reduced from $210 \mathrm{~km}$ to $130 \mathrm{~km}$, from south to north across the Tiburon Rise (see Ngokwey, et al., 1984). The thickness of sediment on the oceanic basement (Fig. 4) shows an increase to the west-northwest that represents the bending of the northern edge of the Tiburon Rise toward the subduction zone. The slope of the Tiburon Rise is interrupted by a few NW to SE- and NE to SW-trending faults which are a common structural pattern of the Atlantic plain in this area (Westbrook, et al., 1984; Fontas, et al., 1984). Displacements along these faults are, at least in part, of pre-Eocene age and probably related to the early stages of oceanic lithosphere formation and subsidence. The thickness of accreted deposits above the décollement (Fig. 4) shows a contrasting trend. The regular westward thickening of the accretionary prism reflects the progressive accretion of Neogene strata without any apparent effect from the structural grain of the underthrust basement. The average seafloor deepening to the northeast (Fig. 1) appears as a result of the west-northwest deepening of the basement.

\section{RESULTS FROM DSDP LEG 78A}

The principal goal of Leg 78A was to drill through the toe of the accretionary prism. The northern Barbados Ridge area has been a favored area for drilling owing to clear seismic definition of the décollement and underlying oceanic crust, moderate water depths, and acceptable total depth to basement (Fig. 5, Backpocket, and Fig. 6). Although this major objective was not achieved during the short 1-month leg, holes at two sites did penetrate to near or within the décollement, and provided clear evidence of accretion and thrust faulting of the incoming oceanic sediment column. Moreover, the apparent discovery of overpressured fluids in the décollement and related faults provided the impetus for a range of hydrogeologic investigations during ODP Leg 110.

Coring at DSDP Sites 541 and 542 arcward of the deformation front recovered a lower Miocene to Holocene sedimentary section composed of marly nannofossil ooze interbedded with smectitic mud-mudstone, underlain by radiolarian clay (at Site 541). See Figure 7 and Biju-Duval, Moore, et al. (1984). Ash beds make up a minor but conspicuous portion of the cored section. Clear lithologic similarities between sediments at Sites 541 and 542 arcward of the deformation front and Site 543 on the oceanic plate argue for offscraping of sediments recovered at the former sites. The upper $200 \mathrm{~m}$ of the incoming oceanic section 


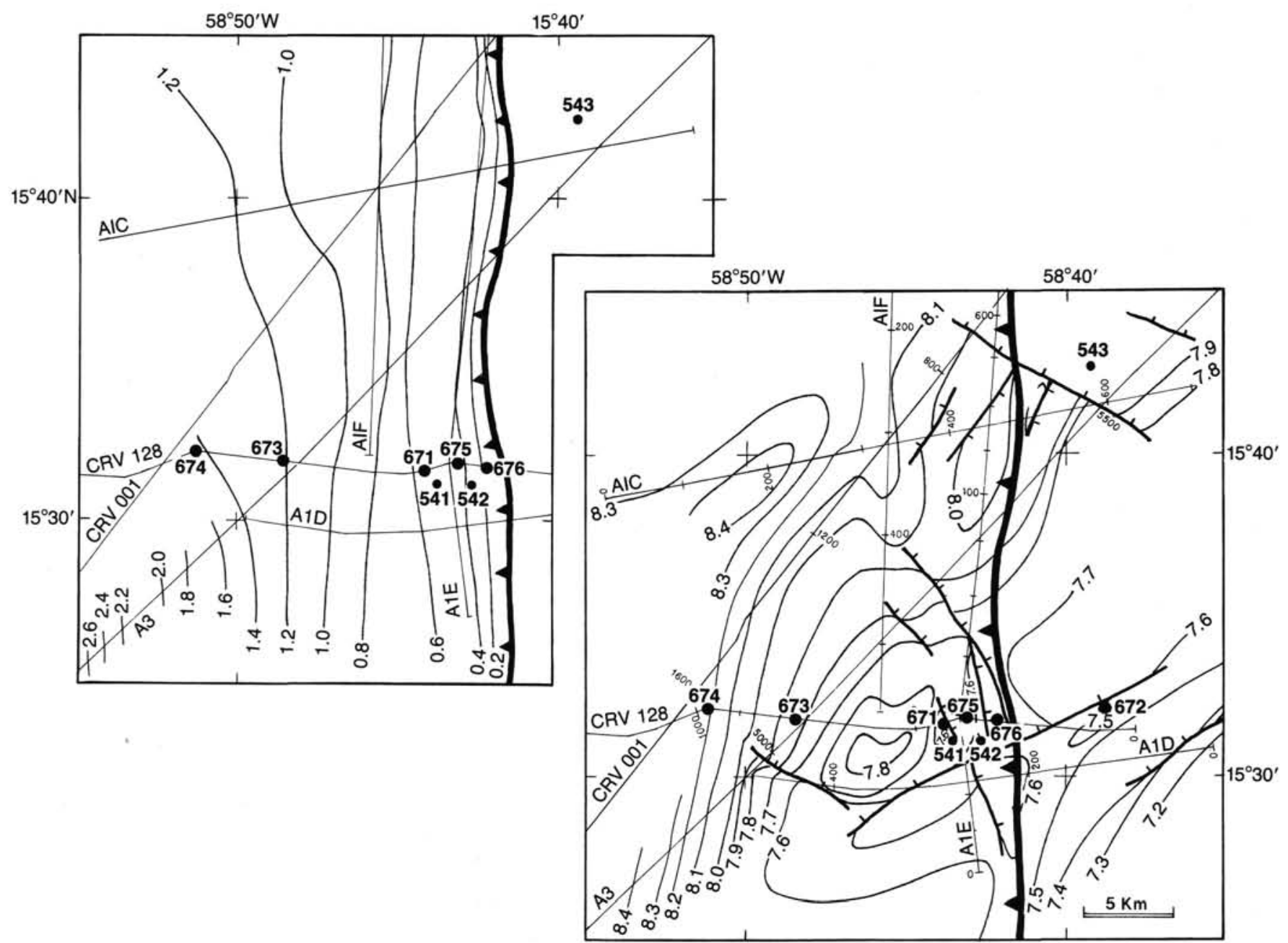

Figure 4. Locations of DSDP Leg 78A and ODP Leg 110 sites. Left: Thickness of accreted series above the décollement. Right: Depth to the oceanic basement. Units of both are seconds, two-way traveltime. The location of seismic profiles has been slightly modified from the original map to take into account the crossing-point correlations between profiles and the water depths given by the Seabeam map.

apparently is being incorporated into the accretionary prism while the section below is at least initially being underthrust with the oceanic crust.

Five thrust faults with throws of up to $70 \mathrm{~m}$ were defined by biostratigraphic inversions at Site 541 and 542 (Figs. 7 and 8). Site 541 ended in the décollement separating the offscraped and underthrust material whereas Site 542 bottomed in a thrust zone, just above the décollement surface. Neither the major faults nor the décollement are discrete surfaces but are deformation zones tens of meters thick characterized by fracturing and scaly fabrics. Bedding dips in the offscraped material averaged about 25 degrees with no overturned surfaces, suggesting a preponderance of thrust faulting and not overturned folding (Cowan, et al., 1984).

In a final attempt to penetrate through the décollement at Site 542, a 60 -m string of drill-in casing was emplaced in an unstable fault zone just above the décollement. The casing became stuck because of the collapse of surrounding sediment and unexpectedly provided a closed conduit to the surface. Immediately following sticking, abnormally high pressures and water flow occurred on the rig floor. Apparently, the fault zone surrounding the casing was overpressured. Moreover, drilling fluid could be pumped easily into the fault zones, suggesting that its foliated mudstone gouge had a high fracture permeability. Ele- vated temperatures in the cored section and in the open holes at Sites 541 and 542 suggest upward flow of porewater, also consistent with abnormal fluid pressures (Davis and Hussong, 1984).

\section{SPECIFIC OBJECTIVES OF LEG 110}

Study of the geologic and hydrologic evolution of the northern Barbados Ridge was approached through three sites located near the deformation front of the accretionary prism, by a single site on the adjacent oceanic plate, and by two sites upslope, substantially arcward of the deformation front (Backpocket Fig. 5). Sites 671,675 , and 676 are all located within $4 \mathrm{~km}$ of the deformation front of the northern Barbados Ridge. Coring there was designed to achieve the principal goal of leg 110, complete penetration of the accretionary prism and underthrusting oceanic sedimentary sequence. Although none of the holes reached completely to the oceanic crust, all were drilled into the décollement zone separating the overthrusting and underthrusting plates. Furthermore, coring at Site 671 penetrated some 150 $\mathrm{m}$ below this surface into the subjacent sedimentary sequence. Coupled with Sites 541 and 542 from DSDP Leg 78a, the Leg 110 sites near the deformation front provided an opportunity to study the geologic and hydrologic processes associated with the initial accretionary process. 


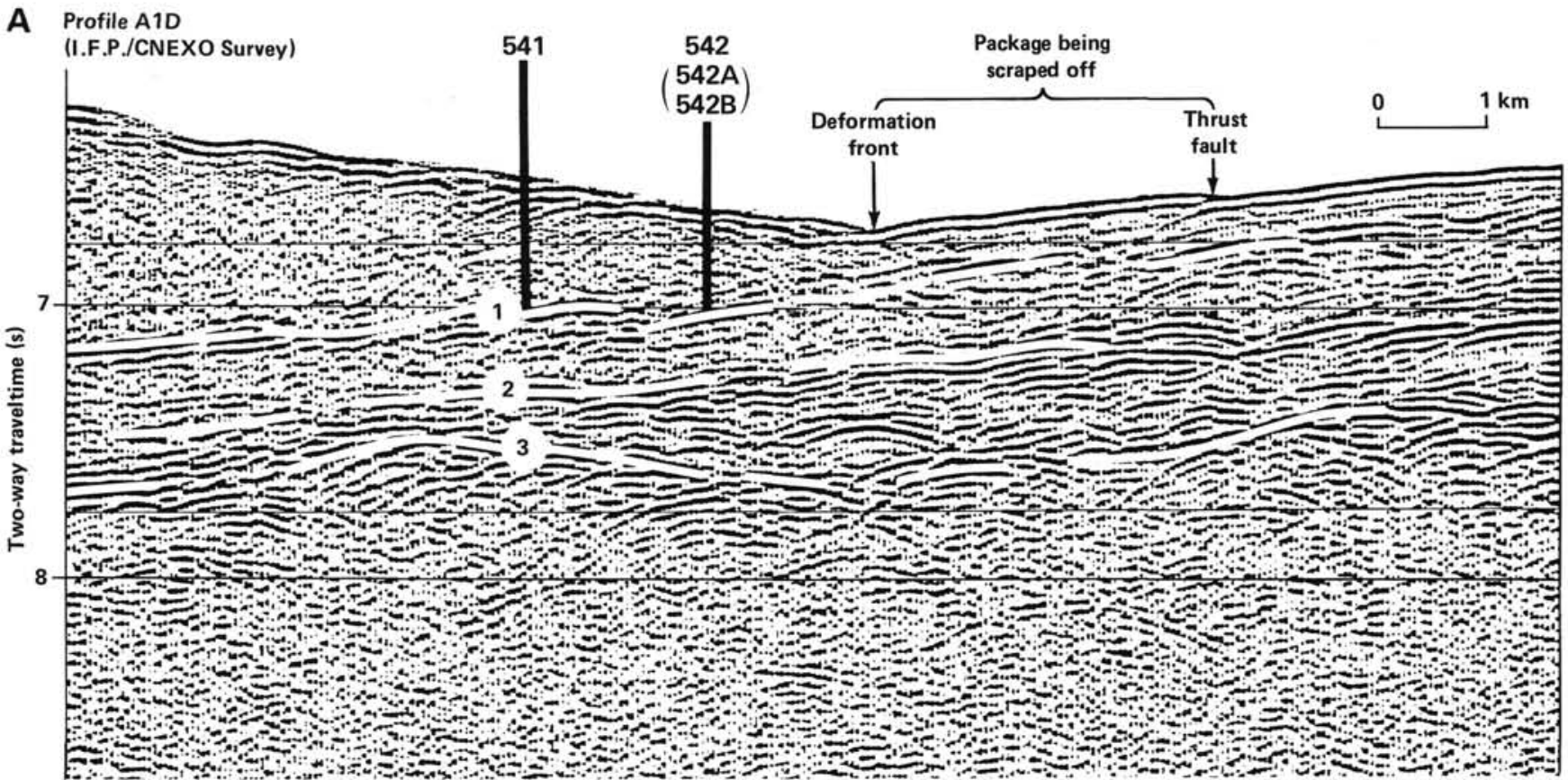

B Profile A1C

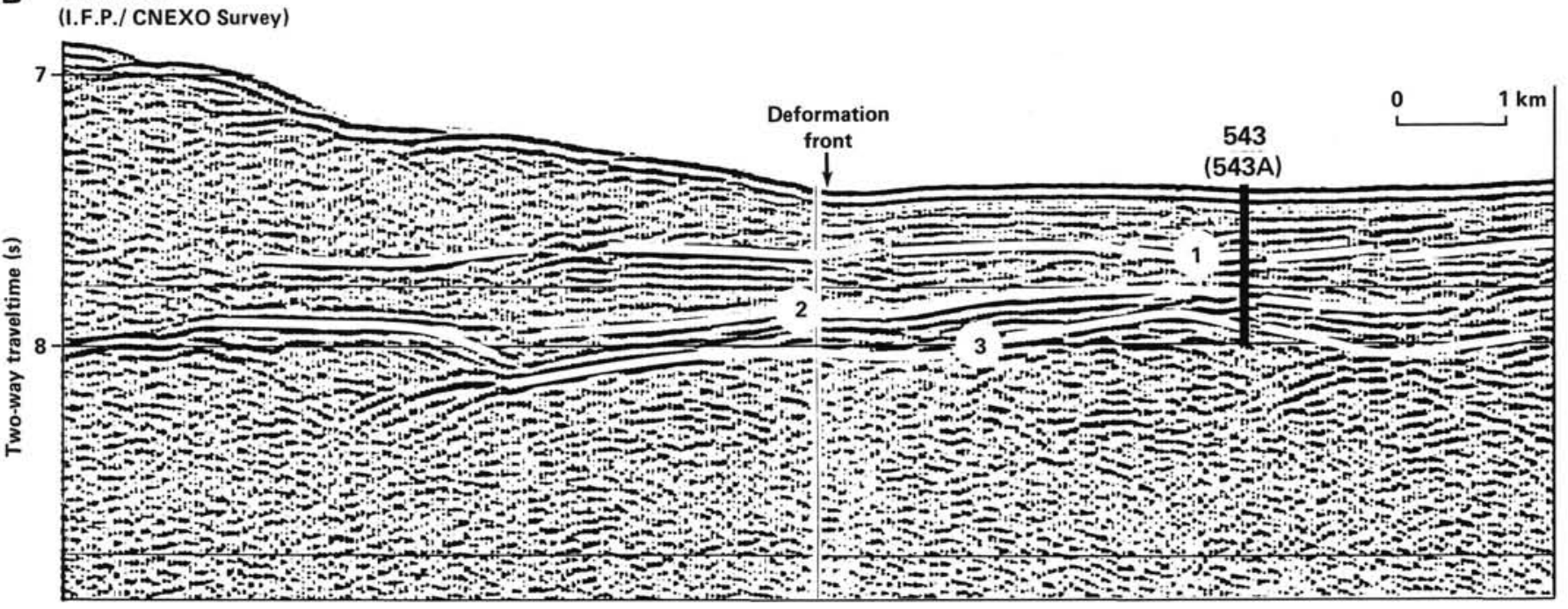

Figure 6. Seismic profiles along which Leg 78A sites were located (Ngokwey, et al., 1984). See Figures 1 and 4 for locations of profiles. Circles locate reflectors. West of the deformation front, Reflector 1 separates the discontinuously reflective seismic unit from the acoustically layered unit below; this surface is interpreted as a décollement. The equivalent stratigraphic level has also been projected seaward as Reflector 1 . Reflector 3 marks the top of the oceanic crust. Reflector 2 separates two parts of the acoustically layered unit: an upper tabular sequence and a lower portion of variable thickness. On Line A1D the thrust fault $3 \mathrm{~km}$ east of the deformation front appears to sole out near Reflector 1 and defines the eastern limit of the sediment package presently being scraped off.

Site $\mathbf{6 7 2}$ was drilled on the adjacent oceanic plate to obtain an oceanic reference section in sediments directly equivalent to those being offscraped and underthrust along the Leg 110 transect. The goal of Site 672 was to provide a baseline on virtually every lithologic, paleontologic, physical and chemical aspect of the sediments entering the subduction zone. The previous reference site (Site 543), $20 \mathrm{~km}$ to the north, sampled a sedimentary sequence of approximately half the thickness of that shown on the seismic reflection line at Site 672 and would not have provided an adequate standard for sites of the Leg 110 transect.

The principal goals of Sites 673 and 674 were to define the continuing structural and hydrologic evolution of the offscraped sediments. An essential objective there was to sample sediments in different evolutionary stages of the accretionary prism between its inital offscraping, well defined at Sites 671, 675, 676, and its final state of uplift locally at Barbados.

\section{Technological and Scientific Approaches of Leg 110}

Because Leg 110 was attempting to drill in active fault zones in partially consolidated sediments, special drilling technology was made available. Moreover, the topical focus on structural and hydrological studies required a specific scientific program aided by both logging and downhole measurements, the latter to include a temperature probe, interstitial water sampler, and a packer. 

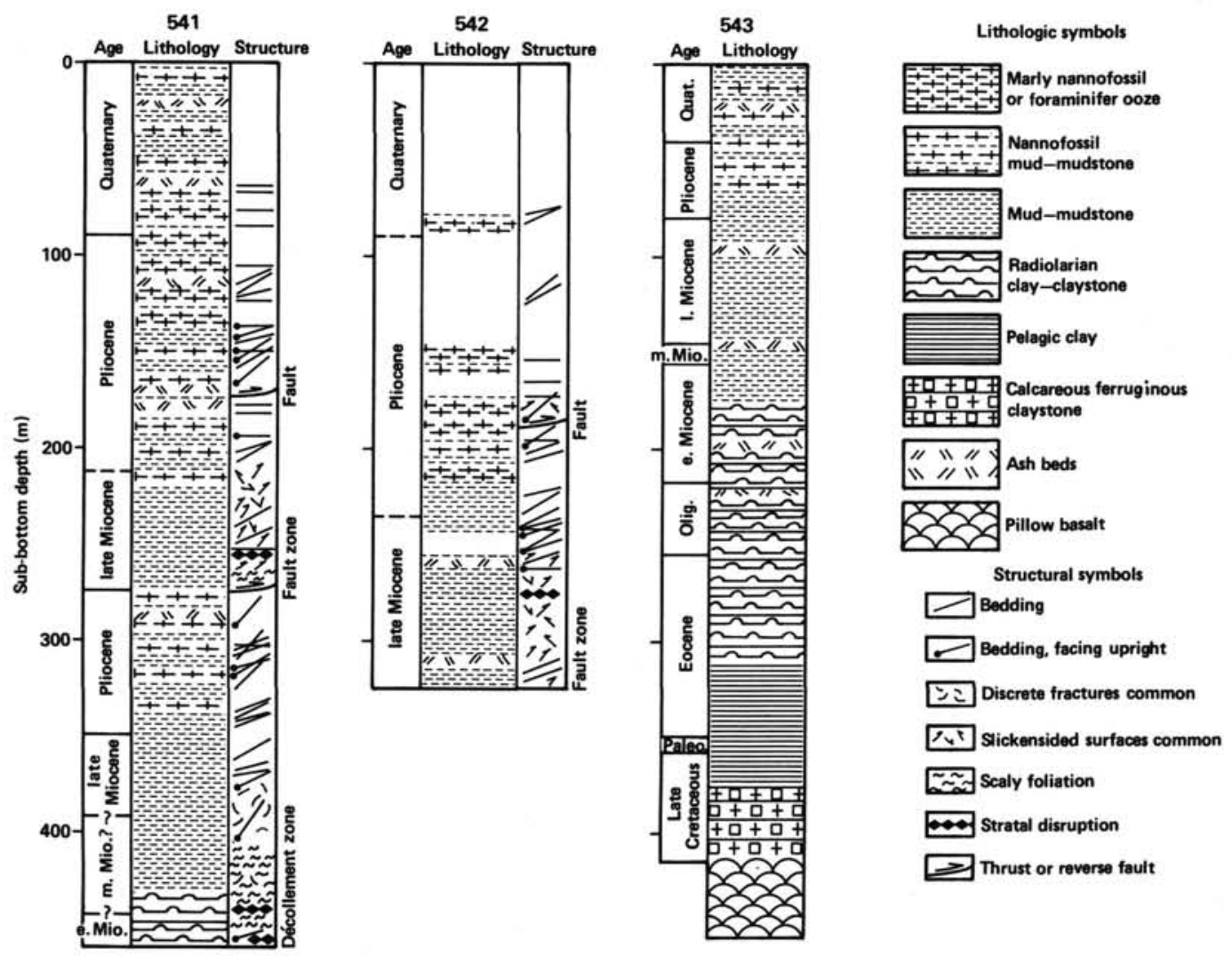

Figure 7. Lithostratigraphy and structural geology of the cores from Leg 78A.

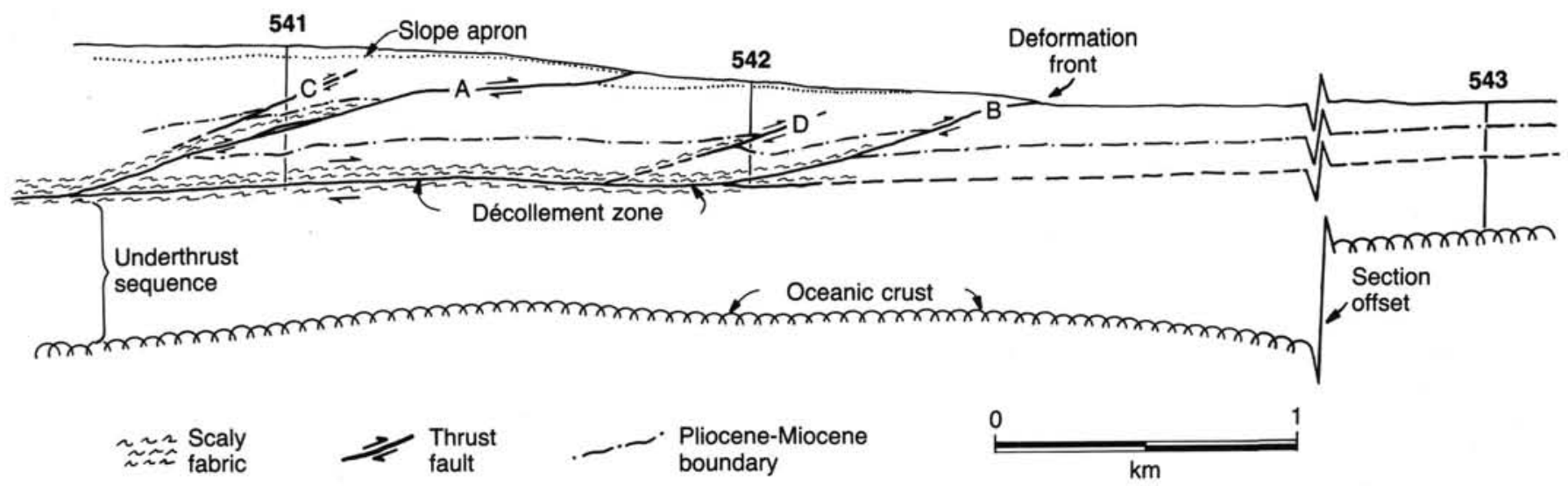

Figure 8. Cross section through Sites 541 and 542 showing major faults and décollement. The section from Site 543 is also shown for reference. The break in this figure represents a lateral offset of about $20 \mathrm{~km}$ (see Fig. 1).

The lack of penetration through the décollement surface during Leg 78a was apparently caused by high fluid pressures and unstable hole conditions. to overcome these problems, ODP engineering and operations personnel designed a drilling plan that included careful maintenance of conditions in an open hole. A casing string capable of extending from the mudline through the décollement zone was also available aboard ship for control of unstable conditions. Moreover, drill-in casing, specifically designed to span only the décollement zone, could have been utilized in a final effort to penetrate this interval.

The results from Leg 78a suggested localization of fluid flow along faults. Accordingly, our drilling strategy focused on rec- ognition of these surfaces biostratigraphically, coupled with intensive investigation of their structural fabrics, physical properties, thermal characteristics, and fluid compositions. We also planned an extensive logging program to define in situ sediment and fluid characteristics. A special drill-in packer was developed for Leg 110 to directly measure fluid pressures, permeabilities, and flow rates in the sedimentary section.

\section{EXPLANATORY NOTES}

In this section we have assembled information that will help the reader understand the basis for our preliminary conclusions 
and help the interested investigator select samples for further analysis. Standard procedures for both drilling operations and preliminary shipboard analyses of the material recovered have been regularly amended and upgraded since 1968 during Deep Sea Drilling Project and Ocean Drilling Program drilling. This section deals only with shipboard operations analyses and interpretations described in the site reports in Part A of the Leg 110 Proceedings of the Ocean Drilling Program. Methods used by various investigators for further shore-based analyses of Leg 110 data will be detailed in the individual scientific contributions published in Part B of the Proceedings.

\section{AUTHORSHIP OF SITE REPORTS}

Authorship of the site reports is shared among the entire shipboard scientific party, although the two co-chief scientists and the staff scientist edited and rewrote part of the material prepared by other individuals. The site chapters are organized as follows (authors in parentheses):

Site Summary (Mascle, Moore)

Background and Objectives (Mascle, Moore)

Operations (Hayes, Taylor, Thompson)

Lithostratigraphy (Beck, Dolan, Ogawa, Schoonmaker, Vrolijk)

Structural Geology (Behrmann, Brown)

Biostratigraphy (Andreieff, Clark, Sakai)

Paleomagnetics (Hounslow)

Geochemistry (Blanc, Gieskes)

Physical Properties (McLellan, Moran, Taylor, Wilkens)

Seismic Stratigraphy (Mascle, Moore)

Heat Flow (Fisher, Hounslow)

Packer Experiments (Fisher)

Logging Results (Alvarez, Williams)

Conclusions (Mascle, Moore)

Following the text are summary graphic lithologic and biostratigraphic logs, core descriptions (barrel sheets), and photographs of each core.

\section{SURVEY AND DRILLING DATA}

The survey data used for specific site selections are discussed in each site chapter. En route between sites, continuous observations were made of depth and sub-bottom structure, and magnetic field. Short surveys using a precision echo sounder and seismic profiles were made on JOIDES Resolution before dropping the beacon at each site. All geophysical data collected during Leg 110 are presented in the "Geophysical Profiling" chapter (this volume).

The seismic profiling system on JOIDES Resolution consisted of two 80 -in. ${ }^{3}$ and one 400 -in. ${ }^{3}$ water gun, a Scripps-designed hydrophone array, Bolt amplifiers, two bandpass filters, and two EDO recorders, usually recording at different filter settings.

Bathymetric data were displayed on $3.5-$ and $12-\mathrm{kHz}$ precision depth recorder systems which consist of sound transceiver, transducer, and recorder. The depths were read on the basis of an assumed $1500 \mathrm{~m} / \mathrm{s}$ sound velocity for water. The water depth (in meters) at each site was corrected (1) according to the Matthew's Tables (1939) and (2) for the depth of the hull transducer $(6 \mathrm{~m})$ below sea level. In addition, depths referred to the drilling platform level are assumed to be $10 \mathrm{~m}$ above the water line.

\section{Drilling Characteristics}

Water circulation through the drill pipe downhole is open, thus cuttings are lost onto the seafloor and cannot be examined.
The only available information about sedimentary stratification in uncored or unrecovered intervals, other than from seismic data or wireline logging results, is from an examination of the behavior of the drill string as observed on the drill platform. The harder the layer being drilled, the slower and more difficult it usually is to penetrate. There are, however, a number of other factors, such as pump pressure and bit configuration, which determine the rate of penetration, so it is not always possible to relate rate of penetration directly to the hardness of the layers. The parameters of bit weight and revolutions per minute are recorded on the drilling recorder and influence the rate of penetration.

\section{Drilling Deformation}

When cores are split, many show signs of significant sediment disturbance. Such disturbance includes the concave-downward appearance of originally horizontal bands, the haphazard mixing of lumps of different lithologies, and the near-fluid state of some sediments recovered from tens to hundreds of meters below the seafloor. Core deformation probably occurs during one of three different steps at which the core can suffer stresses sufficient to alter its physical characteristics: cutting, retrieval (with accompanying changes in pressure and temperature), and core handling.

\section{SHIPBOARD SCIENTIFIC PROCEDURES}

\section{Numbering of Sites, Holes, Cores, and Samples}

ODP drill sites are numbered consecutively from the first site drilled by Glomar Challenger in 1968. Site numbers are slightly different from hole numbers. A site number refers to one or more holes drilled while the ship is positioned over a single acoustic beacon. Several holes may be drilled at a single site by pulling the drill pipe above the seafloor, moving the ship some distance from the previous hole, and then drilling another hole. For all ODP drill sites, a letter suffix distinguishes each hole drilled at the same site; the first hole being designated $\mathrm{A}$ and proceeding alphabetically thereafter at a given site.

The cored interval is measured in meters below the seafloor (mbsf). The depth interval of an individual core extends from the depth below seafloor that the coring operation began to the depth that the coring operation ended. Each coring interval is up to $9.7 \mathrm{~m}$ long, which is the maximum length of a core barrel. The coring interval may, however, by shorter. "Cored intervals" are not necessarily adjacent to each other but may be separated by "drilled intervals." In soft sediment, the drill string can be "washed ahead" with the core barrel in place but not recovering sediment, by pumping water down the pipe at high pressure to wash the sediment out of the way of the bit and up the space between the drill pipe and wall of the hole; however, if thin, hard rock layers are present, it is possible to get "spotty" sampling of these resistant layers within the washed interval.

Cores taken from a hole are numbered serially from the top of the hole downward. Maximum full recovery for a single core is $9.6 \mathrm{~m}$ of sediment or rock in a plastic liner (6.6 cm I.D.), plus about a 0.2 -m-long sample (without a plastic liner) in a core catcher. The measured core length on deck may actually be greater, generally owing to core and gas expansion. The core catcher is a device at the bottom of the core barrel that prevents the core from sliding out when the barrel is being retrieved from the hole. The sediment core, which is in the plastic liner, is then cut into $1.5-\mathrm{m}$-long sections that are numbered serially from the top of the sediment core (Fig. 9 ). When full recovery is obtained, the sections are numbered from 1 through 7 (from the top of the core downward), the last section being shorter than $1.5 \mathrm{~m}$. For sediments, the core-catcher sample is placed below 


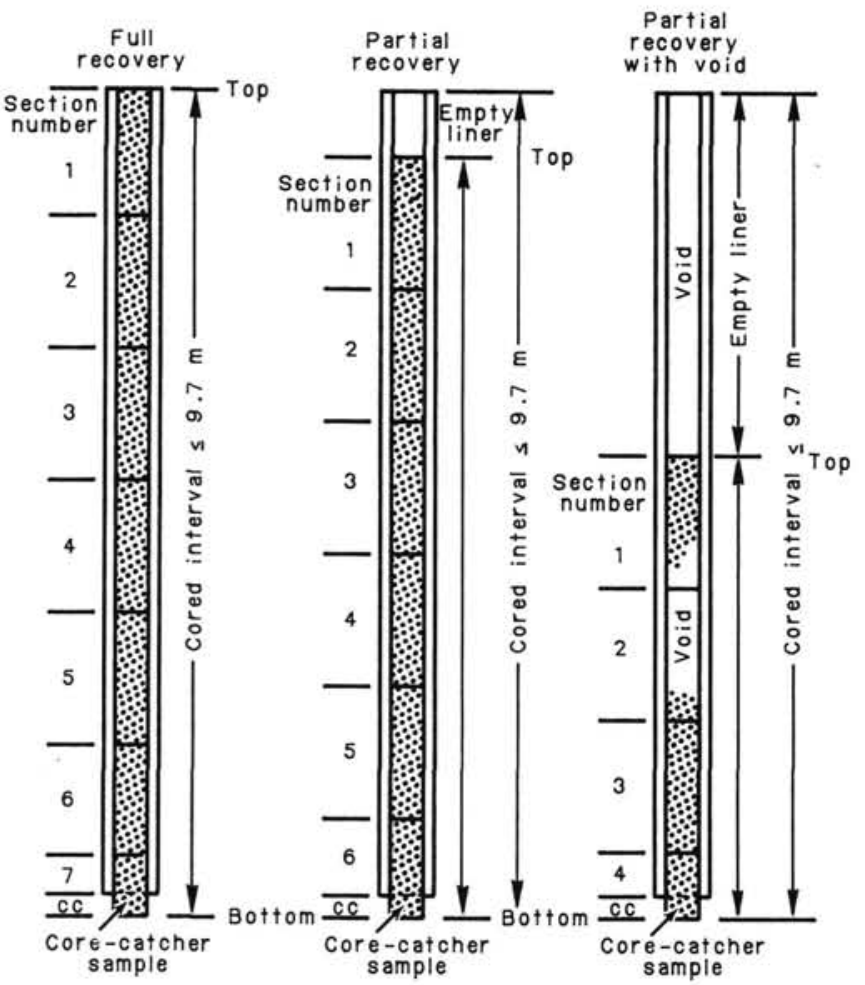

Figure 9. Diagram showing procedure used in cutting and labeling core sections.

the last section and treated as a separate section. For hard rocks, material recovered in the core catcher is included at the bottom of the last section.

When recovery is less than $100 \%$, whether or not the recovered material is contiguous, the recovered sediment is placed at the top of the cored interval, and then 1.5-m-long sections are numbered serially, starting with Section 1 at the top. There will be as many sections as needed to accommodate the length of the core recovered (Fig. 9); for example, $3 \mathrm{~m}$ of core sample in a plastic liner will be divided into two 1.5 -m-long sections. Sections are cut starting at the top of the recovered sediment, and the last section may be shorter than the normal $1.5 \mathrm{~m}$ length. If, after the core has been split, fragments which are separated by a void appear to have been contiguous in situ, a note is made in the description of the section.

Samples are designated by distances in centimeters from the top of each section to the top and bottom of the sample interval in that section. A full identification number for a sample consists of the following information: (1) Leg, (2) Site, (3) Hole, (4) Core Number, (5) Core Type, (6) Section, and (7) Interval in centimeters. For example, the sample identification number "110$672 \mathrm{~A}-3 \mathrm{H}-2,98-100 \mathrm{~cm}$ " means that a sample was taken between 98 and $100 \mathrm{~cm}$ from the top of Section 2 of Core 3 (hydraulic piston core), from the first (and in this case, only) hole drilled at Site 672 during Leg 110. A sample from the core catcher of this core might be designated " $110-672 \mathrm{~A}-3 \mathrm{H}, \mathrm{CC}(8-9 \mathrm{~cm})$."

The depth below the seafloor for a sample numbered 110$672 \mathrm{~A}-3 \mathrm{H}-2,98-100 \mathrm{~cm}$ is the sum of the depth to the top of the cored interval for Core $3(14.3 \mathrm{~m})$ plus the $1.5 \mathrm{~m}$ included in Sections 1 plus the $98 \mathrm{~cm}$ below the top of Section 2. The sample in question is therefore located at $16.78 \mathrm{mbsf}$ which, in principle, is the sample sub-seafloor depth (Note: sample requests should refer to a specific interval within a core section, rather than sub-bottom depths in meters).
ODP core and sample identifiers include "core type." This qualifier designates the drilling and coring method used to obtain a given core. The following abbreviations are used to describe core type: $\mathrm{R}$ = rotary barrel; $\mathrm{H}=$ hydraulic piston core (HPC); $\mathrm{P}=$ pressure core barrel (PCB); $\mathrm{X}=$ extended core barrel (XCB); $\mathrm{B}=$ drill bit recovery; $\mathrm{C}=$ center bit recovery; $\mathrm{I}=$ in-situ water sample; $\mathrm{S}=$ side wall sample; $\mathrm{W}=$ wash core recovery; $\mathrm{N}=$ Navidrill core barrel (NCB); and $\mathrm{M}=$ miscellaneous material. HPC, XCB, rotary, and wash coring were all used at some point during Leg 110 operations.

\section{Core Handling}

As soon as a core is retrieved on deck, it is checked for potential hydrocarbons and a sample is taken from the core catcher to the paleontological laboratory for an initial assessment of the age of the sample.

The core is then placed on a long horizontal rack and gas samples are taken by piercing the core liner and withdrawing gas into a vacuum-tube sampler (Vacutainer). Voids within the core are sought as sites for the gas sampling. Some of the gas samples are stored for shore-based study, but some are analyzed immediately, as part of the safety and pollution-prevention program. Next, the core is marked into section lengths, each section is labeled, and the core is cut into sections. Interstitial water (IW), organic geochemistry (OG), and physical properties (PP). Whole-round samples are taken at this time as well as small samples from the base of some sections for gas head-space analysis. These whole-round samples are capped with red end caps (no acetone) and taped. Each of the core sections is sealed top and bottom by gluing on a plastic cap, blue to identify the top of a section and clear for the bottom. A yellow cap is placed on a section end from which a whole-round core sample has been removed. The caps are attached to the liner by coating the end of the liner and the inside rim of the end cap with acetone. The top cap of one section from each core was generally not glued with acetone until a vane-shear-strength test had been run in that section end.

The cores are then carried into the laboratory, where the sections are again labeled and the core-section identifier is engraved on the liner. The length of core in each section and the core-catcher sample is measured to the nearest centimeter, and this information is logged on the shipboard corelog data-base program.

The cores are then allowed to warm to room temperature before splitting (usually 2 to $4 \mathrm{hr}$ ). During this time, the wholeround sections are run through the GRAPE (gamma-ray-attenuation porosity evaluation) and $P$-wave logger device for estimating bulk density and compressional wave velocity (see below; Boyce, 1976). A significant number of sections were also passed through a magnetic susceptibility loop (see below). After the cores reach thermal equilibrium, thermal conductivity measurements are made, immediately before cores are split.

Cores of relatively soft material are then split lengthwise into the working and archive halves. The softer cores are split with a wire. In soft sediments, some smearing of material can occur, and to minimize contamination users of the cores should avoid using the very near-surface part of the split core. Semiconsolidated and hard-rock cores are split utilizing a high-speed, waterlubricated, diamond-blade saw.

The working half core is then sampled for both shipboard and shore-based laboratory studies. Each extracted sample, and the name of the investigator receiving the sample, is logged, by location, in the sampling computer program. Records of all removed samples, including both those taken aboard ship and those taken after the cores are returned to the archiving facility, are kept by the Curator at ODP in College Station. The ex- 
tracted samples are sealed in plastic vials or bags and labeled. Samples were routinely taken for shipboard analysis of sonic velocity (Hamilton Frame method), water content (gravimetric analysis), percent calcium carbonate (carbonate bomb), bulk mineralogy (X-ray diffraction, XRD), and other purposes. Many of these data are reported in the site chapters.

The archive half is described visually, supplemented by either smear-slide samples from the archive half or by thin sections from the working half and studied under the petrographic microscope. The archive half is then routed to the pass-through cryogenic magnetometer (see below), and is then photographed in both black and white and color, a whole core at a time.

Both halves are then put into labeled plastic tubes (D-tubes), sealed, and transferred to cold-storage space aboard the drilling vessel. Leg 110 cores were transferred from the ship via refrigerated vans to cold storage at the East Coast Repository, which is at Lamont-Doherty Geological Observatory, Palisades, New York.

\section{LITHOSTRATIGRAPHY}

\section{Sediment Classification and Description}

The classification system used during Leg 110 was devised by the former JOIDES Panel on Sedimentary Petrology and Physical Properties and adopted for use by the JOIDES Planning Committee in March 1974. The core descriptions, smear-slide descriptions, and carbonate bomb $\left(\% \mathrm{CaCO}_{3}\right)$ data, all obtained on board ship, serve as the bases for the graphic core descriptions presented at the end of each site chapter (see example, Fig. 10).

\section{Sediment Disturbance}

The coring technique, which uses a $25-\mathrm{cm}$ diameter bit with a 6-cm diameter core opening, may result in extreme disturbance in the recovered core material. The following disturbance categories are recognized for soft and firm sediments (Fig. 11):

1. Slightly disturbed: Bedding contacts are slightly bent.

2. Moderately disturbed: Bedding contacts have undergone extreme bowing.

3. Highly disturbed: Bedding is completely disturbed, sometimes showing symmetrical diapirlike structure.

4. Soupy: Intervals are water-saturated and have lost all aspects of original bedding.

The following categories are used to describe the degree of fracturing in hard sediments (Fig. 11):

1. Slightly fractured: Core pieces in place, with very little drilling slurry or breccia.

2. Moderately fragmented: Core pieces in place or partly displaced, but original orientation is preserved or recognizable. Drilling slurry surrounds fragments. Commonly associated with "drilling biscuits" created by core-barrel rotation.

3. Highly fragmented: Pieces from the interval cored and probably in the correct stratigraphic sequence (although they may not represent the entire section), but original orientation is totally lost.

4. Drilling breccia: Core pieces have completely lost their original orientation and stratigraphic position. May be completely mixed with drilling slurry.

These categories are coded on the "Drilling Disturbance" column of the core-description sheets (Fig. 10) at the end of each site chapter.

\section{Sedimentary Structures}

The description of sedimentary structures on Leg 110 follows the suggested ODP format with only minor modifications.
All structures observed are indicated on the "Sedimentary Structure" column of the core-description sheets (Fig. 10) at the end of each site chapter. A key to the set of structural symbols used on Leg 110 is given in Figure 11.

\section{Color}

Colors of recovered material were determined with Munsell soil color charts. Colors were determined immediately after the cores were split and while they were still wet. Information on core colors is given in the "Lithologic Description" text on the core-description sheets (Fig. 10) at the end of each site chapter.

\section{Graphic Lithology Column}

The lithologic classification scheme presented here is represented graphically on the core-description sheets (Fig. 10) using the symbols illustrated in Figure 12. Qualifier letters are used as overprints in the following cases:

\section{Zeolitic (A1)}

2. Glauconitic (A3)

\section{Sediment Classification Scheme}

The text of the core-description sheets includes the lithologic name assignment and other information such as color, structures, and textures. Smear-slide data are summarized on a chart in the lower right-hand corner of the core-description sheet. Locations of the smear slides are indicated in the "Samples" column.

Sediment and rock names were defined solely on the basis of composition and texture. Composition is most important for description of those deposits more characteristic of open marine conditions, with texture becoming more important for the classification of hemipelagic and near-shore facies. These data were primarily determined on board ship by (1) visual estimates in smear slides and thin sections with the aid of a microscope, (2) visual observation using a hand lens, and (3) unaided visual observation. Calcium carbonate was measured by using the Coulometrics Carbon Analyzer. These values appear in the column labeled CHEMISTRY on the core-description sheets (Fig. 10). Other geologic features determined were color, sedimentary structures, and firmness.

\section{Firmness}

The determination of induration is highly subjective, but the categories used on Leg 110 are thought to be practical and significant. The criteria of Gealy et al. (1971) are used for calcareous deposits with more than $50 \% \mathrm{CaCO}_{3}$; subjective estimate or behavior in core cutting for transitional sediments with less than $50 \% \mathrm{CaCO}_{3}$, biogenic siliceous sediment, pelagic clay, and terrigenous sediments.

There are three classes of firmness for calcareous sediments:

1. Soft: Sediments which have little strength and are readily deformed under the finger or broad blade of the spatula are termed ooze.

2. Firm: Partly lithified ooze or friable limestone is called chalk. Chalks are readily deformed under the fingernail or the edge of a spatula blade.

3. Hard: Limestone is restricted to nonfriable cemented rock.

Only two classes of firmness were regularly noted for noncalcareous setiments:

1. Soft: Sediment core may be split with a wire cutter. Soft terrigneous sediment, pelagic clay, and transitional calcareous biogenic sediments are termed sand, silt, clay, or mud.

2. Hard: The core is hard (i.e., consolidated or well indurated) if it must be cut with a saw. For these materials, the suffix 


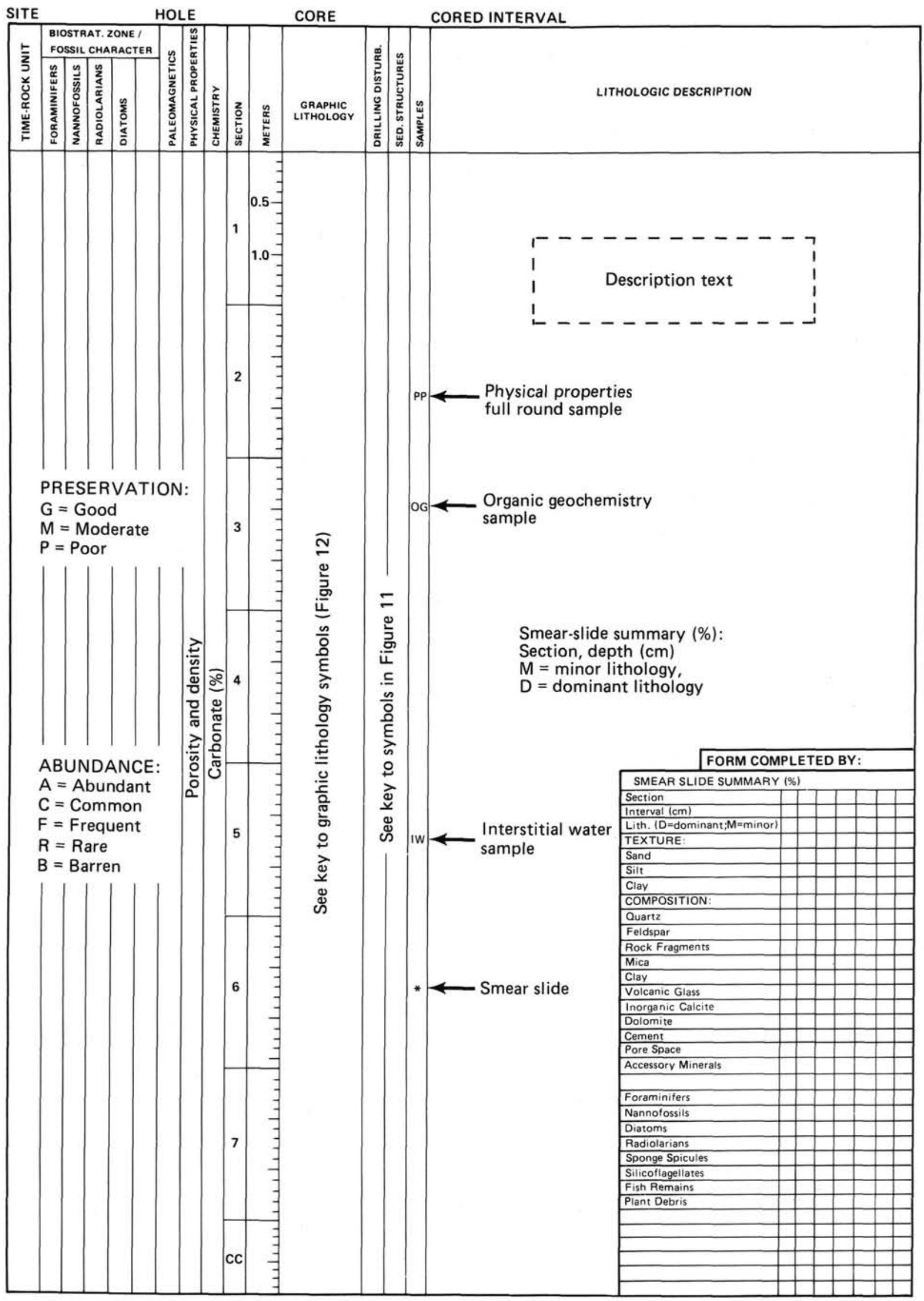

Figure 10. Core-description form ("barrel sheet") used for sediments and sedimentary rocks. 
DRILLING DISTURBANCE

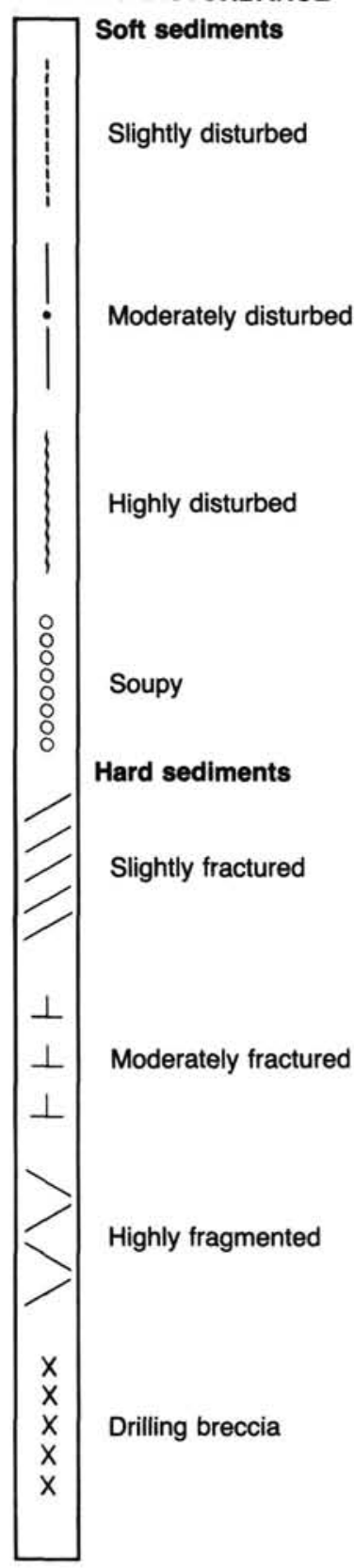

SEDIMENTARY STRUCTURES

\begin{tabular}{|c|c|}
\hline & $\begin{array}{l}\text { Primary structures } \\
\text { Interval over which primary sedimentary structures occur }\end{array}$ \\
\hline$m$ & Current ripples \\
\hline$\mu$ & Micro-cross-laminae (including climbing ripples) \\
\hline & Parallel laminae \\
\hline$w w$ & Wavy bedding \\
\hline $\mathcal{L}$ & Flaser bedding \\
\hline 8 & Lenticular bedding \\
\hline & Slump blocks or slump folds \\
\hline & Load casts \\
\hline$\oslash$ & Scour \\
\hline$\bullet$ & Graded bedding (normal) \\
\hline$\bullet$ & Graded bedding (reversed) \\
\hline $2 \Omega$ & Convolute and contorted bedding \\
\hline if & Water escape pipes \\
\hline & Mud cracks \\
\hline 11 & Cross-stratification \\
\hline & Sharp contact \\
\hline & Scoured, sharp contact \\
\hline & Gradational contact \\
\hline & Imbrication \\
\hline & Fining-upward sequence \\
\hline V & Coarsening-upward sequence \\
\hline & Bioturbation, minor ( $<30 \%$ surface area) \\
\hline il & Bioturbation, moderate ( $30-60 \%$ surface area) \\
\hline 洸 & Bioturbation, strong ( $>60 \%$ surface area) \\
\hline$\gg \gg$ & Discrete Zoophycos trace fossil \\
\hline ○ & $\begin{array}{l}\text { Secondary structures } \\
\text { Concretions }\end{array}$ \\
\hline & Compositional structures \\
\hline 6 & Fossils, general (megafossils) \\
\hline & Shells (complete) \\
\hline$\varnothing$ & Shell fragments \\
\hline$Q$ & Wood fragments \\
\hline & Fault (no relative displacement implied) \\
\hline
\end{tabular}

Figure 11. Symbols used for drilling disturbance and sedimentary structure on core-description forms shown in Figure 10.

-stone is added to the soft-sediment name (e.g., sandstone, siltstone, claystone, mudstone).

\section{Basic Sediment Types}

The following defines compositional class boundaries for the use of qualifiers in the lithologic classification scheme:

\section{Pelagic Clay}

Pelagic clay is principally authigenic pelagic deposits which accumulate at very slow rates. Since all clay-rich sediments cored during Leg 110 show an evident terrigenous origin, this category was not used.

\section{Siliceous Biogenic Sediments}

Siliceous biogenic sediments are distinguished from pelagic clay because they contain common siliceous microfossils. Siliceous biogenic sediments are distinguished from the calcareous category by a calcium carbonate content of less than $30 \%$.

There are two categories of siliceous biogenic sediments: (a) pelagic siliceous biogenic sediments that contain greater than $30 \%$ siliceous microfossils and less than $30 \%$ silt and clay; and (b) transitional siliceous biogenic sediments that contain between $10 \%$ and $70 \%$ siliceous microfossils and greater than $30 \%$ silt and clay. 
Siliceous Biogenic Sediments PELAGIC SILICEOUS BIOGENIC - SOFT
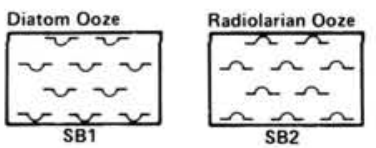

Diatom - Rad or Siliceous Ooze

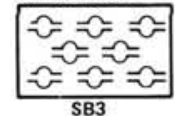

PELAGIC SILICEOUS BIOGENIC - HARD
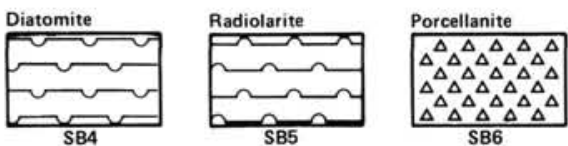

SB6

TRANSITIONAL BIOGENIC SILICEOUS SEDIMENTS

Siliceous Component $<50 \% \quad$ Siliceous Component $>50 \%$

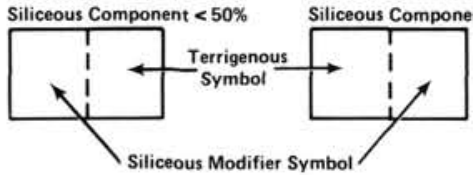

Non-Biogenic

Sediments

Pelagic Clay

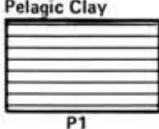

SPECIAL ROCK TYPES
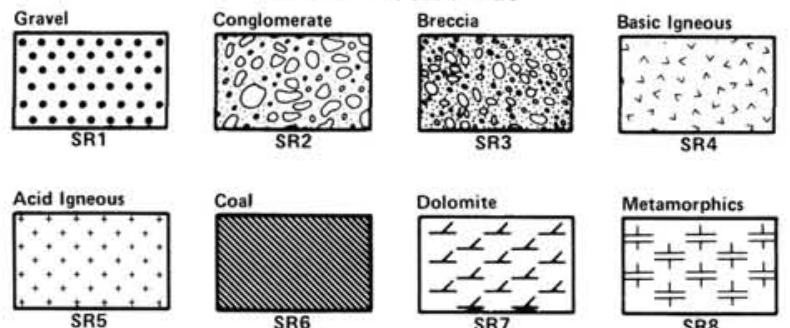

SR8

EVAPORITES

Halite
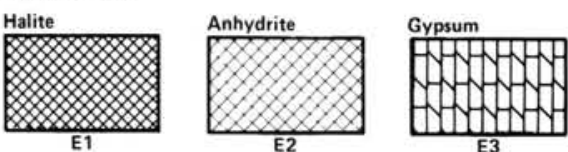

Concretions

Mn*
Manga
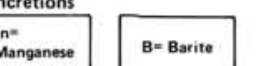

Pe Pyrite

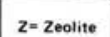

drawn circle with symbol ( others may be designated
Calcareous Biogenic Sediments

PELAGIC BIOGENIC CALCAREOUS - SOFT
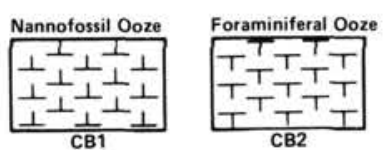

Nanno - Foram or

Foram-Nanno Ooze Calcareous Ooze
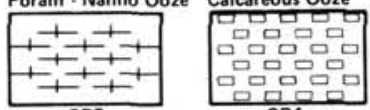

CB4

PELAGIC BIOGENIC CALCAREOUS - FIRM
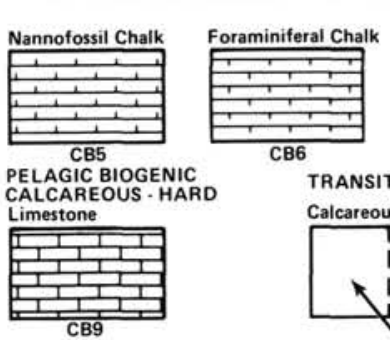

Nanno-Foram or
Foram-Nanno Chalk Calcareous Chalk
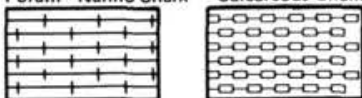

300000
00000

B6

TRANSITIONAL BIOGENIC CALCAREOUS SEDIMENTS

Calcareous Component $<50 \% \quad$ Calcareous Component $>50 \%$

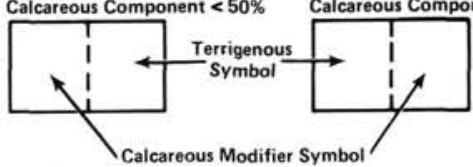

TERRIGENOUS SEDIMENTS
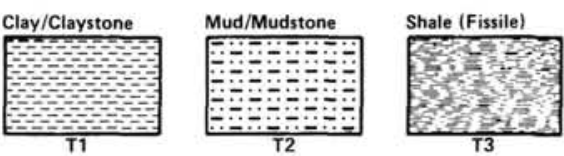

Sandy Mud/

Silt/Siltstone

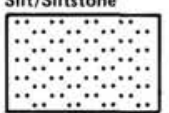

Sand/Sandstone

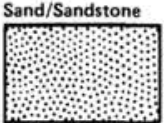

T6

Sandy Silt

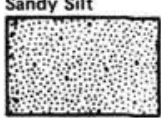

Sandy Clay'

Clayey Sand

.................

..................

…..................

T9

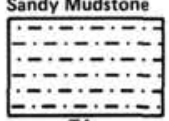

Silty Clay/

Clayey Silt

VOLCANOGENIC SEDIMENTS

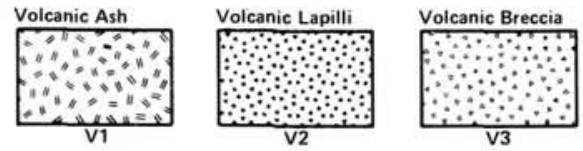

Figure 12. Key to symbols used in "graphic lithology" column on the core-description form shown in Figure 10.

For pelagic biogenic siliceous sediments with $30 \%$ to $100 \%$ siliceous fossils, the following terminology is used:

1. Soft: Siliceous ooze (radiolarian ooze, diatom ooze, etc., depending on the dominant fossil component).

2. Hard: Radiolarite, diatomite, chert, or porcellanite. Diatoms and radiolarians may be the principal components of these sediments; thus one or two qualifiers may be used, for example:

Indeterminate siliceous fossils: Siliceous ooze, chert, or porcellanite.
Radiolarians predominate: Radiolarian ooze, or radiolarite Diatoms predominant: Diatom ooze, or diatomite

Diatoms < Radiolarians: Diatom radiolarian ooze, or diatom radiolarite

Diatoms > Radiolarians: Radiolarian diatom ooze, or radiolarian diatomite

The most dominant component is listed last and the minor component is listed first.

For transitional biogenic siliceous sediments, the following terminology is used: 
1. Siliceous component $<50 \%$ : Diatomaceous mud (soft) or diatomaceous mudstone (hard).

2. Siliceous component $>50 \%$ : Muddy diatom ooze (soft) or muddy diatomite (hard).

Other terms may be substitute for diatomaceous and diatomite, for example, radiolarian or radiolarite, very siliceous, or chert if the fossil type is indeterminate. A calcareous content of between $10 \%$ and $30 \%$ in siliceous biogenic sediments carries a qualifier such as "calcareous," "nannofossil," etc.

\section{Calcareous Biogenic Sediments}

The Leg 110 shipboard party distinguished calcareous biogenic sediment by a biogenic $\mathrm{CaCO}_{3}$ content in excess of $30 \%$, following the standard DSDP and ODP classification scheme. There are two classes: (a) pelagic calcareous biogenic sediments that contain $60 \%$ to $100 \%$ biogenic $\mathrm{CaCO}_{3}$ and (b) transitional calcareous biogenic sediments which contain $30 \%$ to $60 \% \mathrm{CaCO}_{3}$. Calcareous pelagic sediments with near $30 \%$ clay and silt are given the modifier marly, and those containing $30 \%$ to $70 \%$ clay and silt are marls. The term muddy marl reflects the higher amount of clay and silt within this range. Names given to these classes of sediment are consolidation-dependent. Sediments belonging to other classification categories but that contain $10 \%$ to $30 \%$ calcareous components are given the modifier "calcareous" (or "foraminiferal" or "nannofossil", as appropriate). Amounts of $\mathrm{CaCO}_{3}$ less than $10 \%$ were ignored.

\section{Terrigenous Sediments}

Sediments occupying this portion of the classification scheme are subdivided into textural groups on the basis of the relative proportions of three grain-size constituents, i.e., clay, silt, and sand. Coarser terrigenous sediments are usually classed as conglomerate or breccia, clast-supported or matrix-supported, and are treated as "Special Rock Types" (Fig. 12). The size limits for these constituents are those defined by Wentworth $(1922$, see Fig. 13).

Five major textural groups are recognized on the accompanying triangular diagrams (Fig. 14). The groups are defined according to the abundance of clay $(>90 \%, 90 \%$ to $10 \%,<10 \%)$ and the ratio of sand to silt $(>1$ or $<1)$. The terms clay, mud, sandy mud, silt, and sand are used for unconsolidated sediments that are cut with a wire in the shipboard core splitting process. The hard or consolidated equivalents for the same textural groups are claystone, mudstone, sandy mudstone, siltstone, and sandstone. Sedimentary rocks in the consolidated category include those which must generally be cut with a super-saw or diamond saw.

In this sediment category, numerous qualifiers are possible, usually based on minor constituents (for example, glauconitic, pyritic, feldspathic). The most commonly encountered minor constituents during Leg 110 were zeolite and glauconite, represented respectively by $\mathrm{A} 1$ and $\mathrm{A} 3$ overprints. Terrigenous sediments and sedimentary rocks containing $10 \%$ to $30 \% \mathrm{CaCO}_{3}$ are qualified by the modifier "calcareous."

\section{Volcanogenic Sediments}

Clastic sediments of volcanic provenance are described in the same fashion as terrigenous sediments, noting the dominant composition of the volcanic grains where possible. These pyroclastic rocks are furthermore described as vitric (glass), crystal, or lithic.

\section{Shipboard X-ray Diffraction Analysis}

To obtain further information about sediment composition, splits of several samples per core, including all physical-properties samples, were analyzed on the shipboard Philips PW1710/

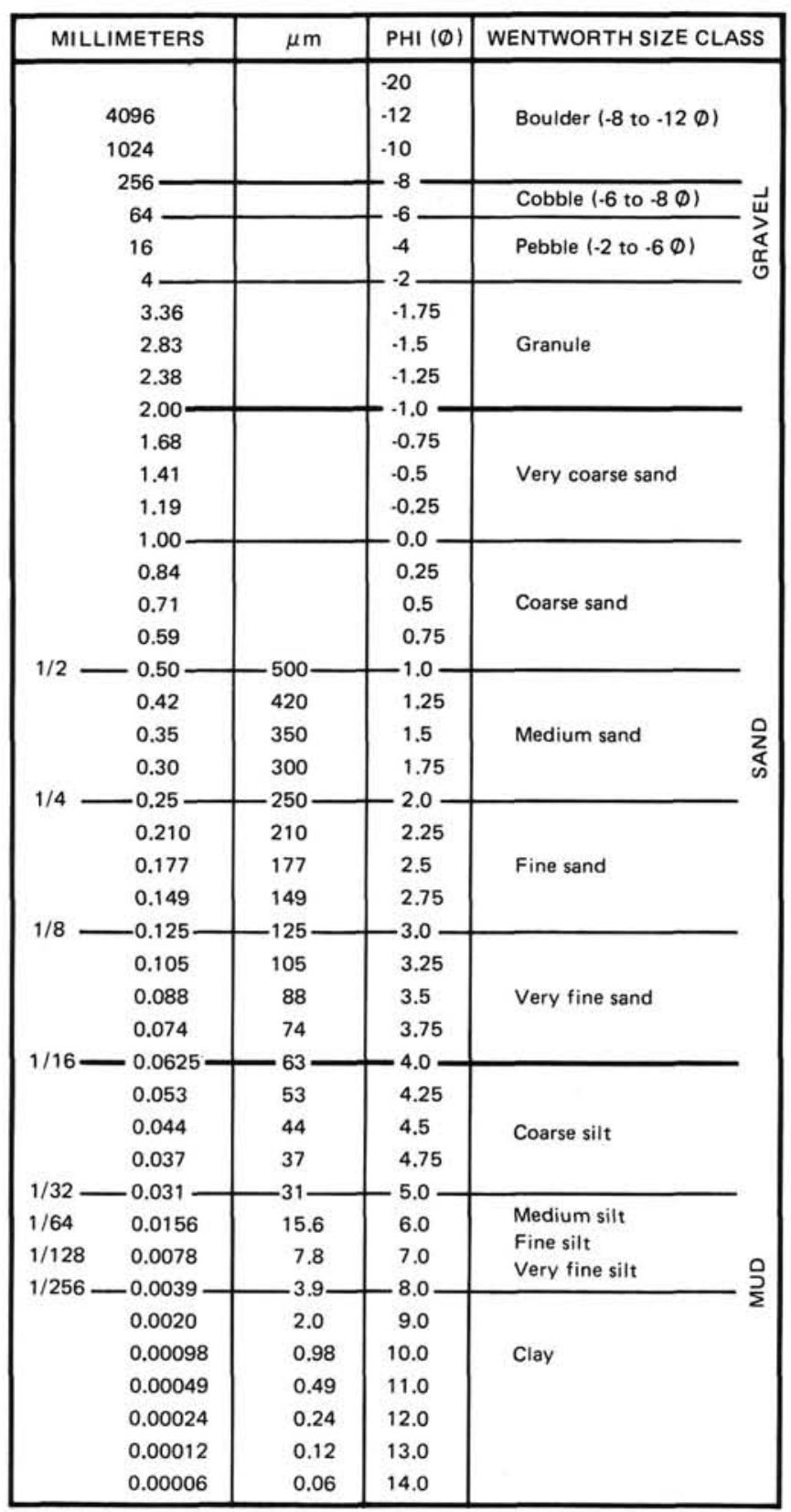

Figure 13. Grain-size categories used for classification of terrigenous sediments (from Wentworth, 1922).

$00 \mathrm{X}$-ray diffraction system for bulk and clay mineralogy. Splits of the samples were freeze-dried, then partitioned prior to carbonate analysis, ground gently with a mortar and pestle, and used to prepare randomly oriented pressed powders. Diffraction profiles were run at $40 \mathrm{kV} / 35 \mathrm{ma}$ using Ni-filtered $\mathrm{CuK} \alpha$ radiation. The samples were step-scanned from either $3^{\circ}$ to $60^{\circ} 2 \theta$ or $3^{\circ}$ to $90^{\circ} 2 \theta$ using a step size of $0.02^{\circ} 2 \theta$ and a counting time of $1.0 \mathrm{~s}$.

Semiquantitative analysis was performed on these samples using the Philips software APD 1700. Percentages of total clay minerals, quartz, plagioclase, and calcite were determined from background-corrected, integrated peak areas for the peaks given in Table 1. Although minor amounts of other minerals were present in some samples, the four phases analyzed make up most $(>95 \%)$ of each sample. The semiquantitative analysis 


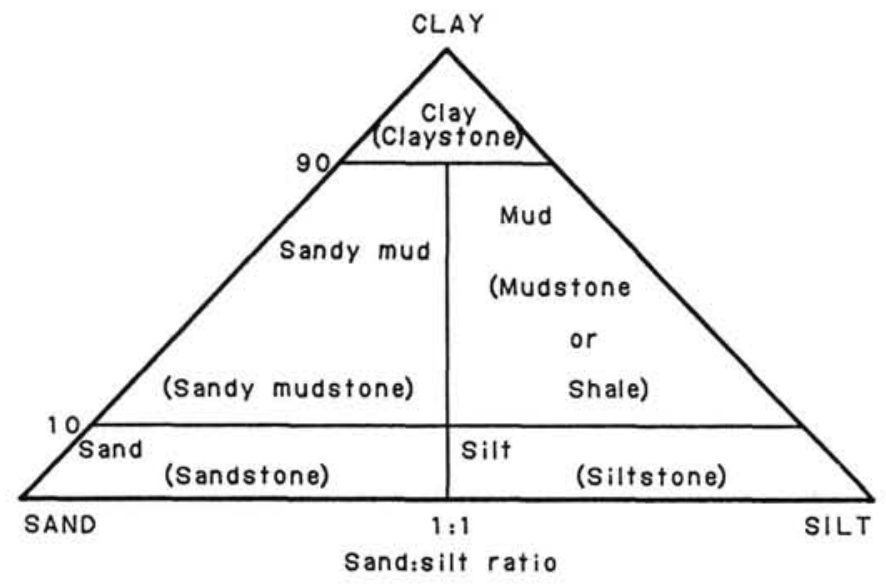

Figure 14. Classification scheme used for terrigenous sediments and sedimentary rocks, Leg 110.

Table 1. Peak locations and $2 \theta$ ranges scanned for phases determined by semiquantitative $X$-ray diffraction analysis.

\begin{tabular}{lcc}
\hline \multicolumn{1}{c}{ Phase } & Approx. peak pos. $(\AA)$ & $2 \theta$ range scanned \\
\hline Total clay & 4.5 & $19.5-20.2$ \\
Quartz & 3.34 & $26.3-26.9$ \\
Plagioclase & $3.18,3.21$ & $27.5-28.1$ \\
Calcite & 3.04 & $29.0-29.6$ \\
\hline
\end{tabular}

program was calibrated using the six standards listed in Table 2. An external check on the accuracy of the semiquantitative analysis was provided by comparing the percentage of calcite as determined by X-ray diffraction with total carbonate measured by coulometric analysis on Site 671 samples (see Site 671 chapter, this volume). The two determinations showed generally good agreement. Oriented pastes were prepared for some samples and were analyzed qualitatively to identify the clay minerals present. Although the estimates of mineral abundances obtained from XRD data by this method are only relative and semiquantitative, they do provide a useful mechanism for comparing compositional changes downcore and between cores.

\section{BIOSTRATIGRAPHY}

\section{Radiolarian Biostratigraphy}

\section{Zonation}

The radiolarian zonation of Riedel and Sanfilippo (1978) was used almost exclusively to describe the silica-rich, lower Miocene through middle Eocene sediments from Leg 110. The Theocyrtis bromia Zone of Riedel and Sanfilippo (1978) of late Eocene age further refined the use of the subzone designations of Saunders et al. (1984).

Table 2. Standard mineral mixtures used to calibrate the semiquantitative analysis.

\begin{tabular}{ccccc}
\hline Standard & $\%$ Total clay & $\%$ Quartz & $\%$ Plagioclase & $\%$ Calcite \\
\hline 1 & 83.9 & 11.3 & 4.8 & 0 \\
2 & 75.2 & 14.6 & 10.2 & 0 \\
3 & 66.9 & 17.7 & 5.2 & 10.2 \\
4 & 58.8 & 16.2 & 5.0 & 20.0 \\
5 & 39.3 & 20.8 & 10.0 & 29.9 \\
6 & 39.2 & 10.8 & 10.0 & 40.0 \\
\hline
\end{tabular}

\section{Abundance and Preservation}

Discussions of abundance of radiolarians in the "Biostratigraphy" sections of the site chapters is based on slides of sieved, acid residues, and consequently they may differ markedly from the lithologic descriptions, which are based on smear slides. Our abundance estimates are completely qualitative, and are based on visual approximations of the total volume of processed residue and the relative frequency of radiolarians in each residue. Based on our long experience with these observations, we suggest that our abundance terms have the following range of absolute frequency:
A (abundant) $=>50,000$ specimens $/ \mathrm{g}$.
$\mathrm{C}($ common $)=10,000-49,000$ specimens $/ \mathrm{g}$.
$\mathrm{F}$ (few) $=1000$ to 9000 specimens $/ \mathrm{g}$.
$\mathrm{T}($ trace $)=<1000$ specimens $/ \mathrm{g}$.

The quality of radiolarian preservation in Leg 110 recovery ranged from poor to good. Degraded preservation was largely a result of dissolution effects. There is little evidence of corrosion pitting or metallic coating.

$\mathrm{G}(\mathrm{good})=$ a majority of whole specimens with spines intact and normal index of refractions.

$\mathbf{M}($ moderate $)=$ many broken specimens, or opal with high index of refraction.

$\mathbf{P}$ (poor) = mostly broken fragments or specimens lacking all delicate lattice components.

\section{Sample Preparation}

Radiolarians were studied from the coarse fraction components $(>44 \mu \mathrm{m})$. As a standard procedure the samples were boiled in $\mathrm{H}_{2} \mathrm{O}_{2}$, sieved, treated with $\mathrm{HCl}$, and then with ultrasound for about $5 \mathrm{~s}$ (repeated several times if the sediment was tough to disintegrate), sieved, and an aliquot of the suspendable part of the residue was mounted on a slide using Canada balsam.

\section{Calcareous Nannofossil Biostratigraphy}

\section{Zonation}

The nannofossil biostratigraphy of Leg 110 is based on the modified zonations of Gartner (1977) for Pleistocene sediments, and Okada and Bukry $(1980)$ and Bukry $(1973,1975)$ for sediments below the Plio-Pleistocene boundary. Zonal modifications adopted in this report are the same as those proposed by Bergen (1984).

Emendations to the Pleistocene zonation are minor. The small gephyrocapsa Zone of Gartner (1977) is difficult to recognize owing to the effects of dissolution on gephyrocapsid abundance. The Pseudoemiliania lacunosa Zone is therefore expanded to contain this interval. The $P$. lacunosa Zone is defined in this report as the interval between the LAD of $P$. lacunosa and the LAD of Helicosphaera sellii.

Changes in the Pliocene zonation scheme are also minor. The top of the late Pliocene is marked, in the zonation of Okada and Bukry (1980) and Bukry $(1973,1975)$, by the LAD of Reticulofenestra pseudoumbilica and the LAD of the genus Sphenolithus. In the Leg 110 zonation scheme the datum is recognized solely by the LAD of Reticulofenestra pseudoumbilica.

The LAD of Amaurolithus tricorniculatus is more consistant than that of $A$. primus in this geographic area (Bergen, 1984) and will be used to designate the top of the $A$. tricorniculatus Zone of Okada and Bukry (1980).

The Miocene/Pliocene boundary is recognized by Okada and Bukry $(1980)$ and Bukry $(1973,1975)$ by the LAD of Triquetrorhabdulus rugosus. Because T. rugosus is frequently found in 
the early Pliocene section, the FAD of Ceratolithus acutus will be substituted as the boundary marker.

\section{Abundance and Preservation}

Abundance of nannofossils was based on the method described by Hay (1970), using a magnification of $1000 \times$. The abundances reported follow the format:

$$
\begin{aligned}
& \mathrm{VA}= \text { very abundant (more than } 10 \text { specimens per field of } \\
& \text { view). } \\
& \mathrm{A}= \text { abundant }(1 \text { to } 10 \text { species per field of view). } \\
& \mathrm{C}=\text { common ( } 1 \text { specimen per } 2 \text { to } 10 \text { fields of view). } \\
& \mathrm{F}=\text { few ( } 1 \text { specimen per } 11 \text { to } 100 \text { fields of view). } \\
& \mathrm{R}=\text { rare ( } 1 \text { specimen per } 101 \text { to } 1000 \text { fields of view). }
\end{aligned}
$$
lows:

The state of nannofossil preservation was designated as fol-

$\mathrm{G}=$ good (Little or no evidence of overgrowth and/or etching of specimen).

$\mathbf{M}=$ moderate (Some degree of overgrowth and/or etching, but identification generally not impaired).

$\mathbf{P}=$ poor (Substantial overgrowth and/or etching, identification of specimens is difficult but still possible).

\section{Sample Preparation}

Samples from sediment-bearing cores were prepared into smear slides and studied with the light-microscope.

\section{Planktonic Foraminifer Stratigraphy}

\section{Zonation}

The zonal scheme established by Bolli et al. (1985) is employed throughout this volume. This zonation, however, was modified in the lower Pliocene sequences recovered during Leg 110 , because of the rarity or absence of the zonal markers Globorotalia margaritae and $G$. miocenica.

Consequently, the Miocene/Pliocene and early/late Pliocene boundaries were tentatively determined on the basis of the FAD of Globigerinoides conglobatus (s.s.) and the LADs of Pulleniatina primalis and/or Globigerinoides obliquus, respectively.

\section{Series/Subseries Boundaries}

The planktonic foraminifer events that were chosen to define Eocene-Pleistocene series and subseries boundaries are:

Base Eocene: Last appearance datum (LAD) Morozovella velascoensis and/or first appearance datum (FAD) Pseudohastigerina wilcoxensis.

Base middle Eocene: FADs Hantkenina and/or Globigerinatheka.

Base late Eocene: LAD "hispid globorotalids" (i.e., Acarinina-Morozovella-Truncorotaloides group).

Base Oligocene: LADs Globorotalia cerroazulensis and/or Hantkenina. Base late Oligocene: LAD Globigerina gortanii.

Base Miocene: FAD Globorotalia kugleri.

Base middle Miocene: FAD Praeorbulina glomerosa.

Base late Miocene: FAD Neogloboquadrina acostaensis.

Base Pliocene: FAD Globigerinoides conglobatus.

Base late Pliocene: LADs Pulleniatina primalis and/or Globigerinoides obliquus.

Base Pleistocene: FAD Globorotalia truncatulinoides. Base late Pleistocene: LAD Globorotalia flexuosa.

\section{Abundance and Preservation}

The abundance of a particular species in the residue assemblage is:

$\mathrm{A}=$ Abundant ( $>40 \%$ of the population).

$\mathrm{F}=$ Frequent $(40 \%$ to $20 \%)$.

$\mathrm{C}=$ Common $(20 \%$ to $5 \%)$.

$\mathrm{R}=\operatorname{Rare}(<5 \%)$.

Preservation includes the effects of diagenesis, epigenesis, abrasion, encrustation, and/or dissolution. The state of preservation used in the volume for foraminifers:

$\mathrm{G}=$ good (dissolution effects rare to obscure).

$\mathbf{M}=$ moderate (specimen dissolution common but minor).

$\mathrm{P}=$ poor (specimen identification very difficult or impossible).

\section{Sample Preparation}

Samples (about $100 \mathrm{~cm}^{3}$ from the core catchers and $10 \mathrm{~cm}^{3}$ from the cores) were soaked in a $10 \%$ solution of hydrogen peroxide and washed through a $63-\mu \mathrm{m}$ mesh, then dried and examined.

Analyses were carried out on the $>150-\mu \mathrm{m}$ fraction.

\section{PALEOMAGNETISM}

Paleomagnetic measurements performed during Leg 110 consist of remanent magnetization and whole-core susceptibility determinations.

\section{Remanent Magnetization Measurements}

Samples were taken by pushing $2.1-\times 2.1-\times 1.45-\mathrm{cm}$ plastic boxes into the sediment, with the fiducial arrow pointing upcore. Samples from more indurated cores where cut, using a stainless-steel knife, to fit inside the plastic boxes. The remanent magnetization of these samples was measured on a Molspin spinner magnetometer using the 6-spin procedure, both on the JOIDES Resolution and in the laboratory at Sheffield University, England. These magnetometers were calibrated so as to take account of the smaller volume of the plastic box samples compared to the standard provided with these instruments. All resulting intensities are in milliamperes per meter $(\mathrm{mA} / \mathrm{m})$. The noise level of these instruments is of the order of $0.05 \mathrm{~mA} / \mathrm{m}$ for these ODP samples.

The samples were progressively demagnetized on the ship using a Schonstedt 3-axis, nontumbling demagnetizer. In the laboratory at Sheffield the samples were demagnetized by a Molspin, 3-axis tumbling demagnetizer.

Behavior during demagnetization was examined using stereographic projections and Zijderveld (vector endpoint) diagrams, which are connected interactively with the program controlling the magnetometer. The basis of the Zijderveld diagram plot is explained in the caption to Figure 24 in the Site 671 chapter.

\section{Whole-Core Susceptibility Measurements}

Whole-core susceptibility was determined with the Bartington MSI meter and the whole-core field loop. Readings from cores of drilling breccia were rejected from the data set, as were data recorded at voids in the cores. The data from the hydraulic piston cores is of the best quality. The XCB coring process tends to mix the lithologies so that the susceptibility signal from a single horizon is spread out, and as a result a large value from a single horizon may be relatively lowered from its true value. The field loop is also most sensitive to the material closest to it so it tends 
to see volumetrically more of the drilling-deformed material just inside the core liner than actually exits, resulting in a smearing of the signal.

During Leg 110 the whole-core susceptibility meter was calibrated with a short length of core liner filled with $\mathrm{MnO}_{2}$. The output from the meter was found to be incorrect and in volume susceptibility units (i.e. susceptibility per $\mathrm{cm}^{3}$ ) of $10^{-6}$ Gauss/ Oersted (G/Oe). The susceptibilities recorded on this leg have been multiplied by 2.06 to make them consistent with this calibration.

\section{GEOCHEMISTRY}

The organic and inorganic geochemistry program for ODP Leg 110 included (1) measurement of hydrocarbon gases, (2) determination of organic and inorganic carbon, (3) characterization of the organic matter by Rock-Eval pyrolisis, and (4) analysis of interstitial water for $\mathrm{pH}$, alkalinity, salinity, sulfate, chlorinity, calcium, magnesium, silica, and ammonia. Samples for geochemical studies were generally recovered from every third core in the lower stratigraphic sections, and at more frequent intervals in the upper section.

\section{Hydrocarbon Gases}

The sampling method for interstitial water dissolved methane analysis was recently improved during the "Hydrotherm" expedition to the Atlantis II Deep (Blanc et al., 1986). Sediment samples for this analysis were taken immediately upon arrival of the cores on deck. A small volume of sediment was placed in a borosilicate glass vial, and the vial was then filled to approximately two thirds of its total volume with sodium azide-poisoned, hydrocarbon-free seawater. The sodium azide $\left(\mathrm{NaN}_{3}\right)$ inhibits any possible microbial activity after sampling. The vial was then capped and sealed with an aluminum ring. The sample was agitated on a high-speed shakeer to partition gas into a helium-filled headspace similar to the method used by Bernard et al. $(1976,1978)$. The headspace methane was then analyzed by gas chromatography on a Hewlett-Packard 5890A. Methane concentrations are then expressed in micromoles per kilogram of seawater, calculated from the sediment dry weight and original water content (see Physical Properties).

\section{Elemental Analysis}

Shipboard organic carbon and total carbon analyses were done using a Perkin-Elmer 240C Elemental Analyzer. For the direct determination of organic carbon, portions of acidified sediment from carbonate analyses were washed with deionized water, and dried at $35^{\circ} \mathrm{C}$. Samples containing about $15-\mathrm{mg}$ of sediment were weighed on a Cahn Electrobalance for elemental analysis. Samples were burned at $1000^{\circ} \mathrm{C}$ in the presence of oxygen, and the volumes of the evolved gases determined as measures of the $\mathrm{C}, \mathrm{H}$, and $\mathrm{N}$ contents of sediment organic matter. Concentrations were determined by the Perkin-Elmer 3600 Data Station and compared with those of known standards. Neither hydrogen or nitrogen results were reproducible nor realistic, and therefore are not reported. Organic carbon values are reported on a dry sediment weight basis. Total carbon was determined in a like manner except that the sediment samples were not acidified. Total carbon was used to calculate organic carbon by taking the difference between total carbon and carbonate carbon.

\section{Carbonate Carbon}

Carbonate carbon was determined by means of the Coulometrics 5030 Carbonate Carbon Apparatus. With the Carbonate Carbon apparatus, about $250 \mathrm{mg}$ of dried, powdered sediment was gently heated and reacted with $\mathrm{HCl}$. The resulting $\mathrm{CO}_{2}$ was transferred to a Coulometer with ethanelamine as the indicator solution. The $\mathrm{CO}_{2}$ was converted to a strong acid and the changing color of the solution was monitored. The results are reported in micrograms $\mathrm{C}$ and percentage $\mathrm{CaCO}_{3}$. Carbonate carbon values from the carbonate bomb and the coulometer were similar except that the coulometer was more sensitive.

\section{Rock-Eval Procedure}

The source character and maturity of organic matter in selected sediment samples were determined with the shipboard Delsi Nermag Rock-Eval II pyrolysis instrument. About $100 \mathrm{mg}$ of nonacidified, coarsely ground dried sediment was heated from $250^{\circ} \mathrm{C}$ to $550^{\circ} \mathrm{C}$ at a rate of $25^{\circ} \mathrm{C} / \mathrm{min}$. Gases released during this heating were carried off in a helium stream, which was split into two parts. One part was directed through a flame ionization detector to monitor hydrocarbons; the other passed through a $\mathrm{CO}_{2}$ trap from which the total amount of evolved $\mathrm{CO}_{2}$ was released at the end of the heating program to be measured by a thermal conductivity detector.

This pyrolysis procedure yields four parameters that characterize the organic matter in a sample (Tissot and Welte, 1984):

1. Area of peak $S_{1}$, which corresponds to the quantity of free hydrocarbons present in the sample.

2. Area of peak $S_{2}$, which corresponds to the quantity of hydrocarbons released by pyrolysis of kerogen up to $550^{\circ} \mathrm{C}$.

3. Temperature, $T_{\max }$, at the top of peak $S_{2}$, which is related to the maturity of the organic matter.

4. Area of peak $S_{3}$, which corresponds to the $\mathrm{CO}_{2}$ released from pyrolysis of kerogen and is a measure of the amount of oxygen in the kerogen matrix.

From $S_{2}, S_{3}$, and the organic carbon concentration, the hydrogen index ( $\mathrm{HI})$ and oxygen index $(\mathrm{OI})$ can be calculated and used to determine kerogen source, character, and maturity.

\section{Interstitial Waters}

Interstitial waters were routinely analyzed for $\mathrm{pH}$, alkalinity, salinity, sulfate, chlorinity, calcium, magnesium, silica, and ammonia. The method of obtaining interstitial waters from the sediment, using a stainless-steel press, was described in detail by Manheim and Sayles (1974). In essence, 10-cm long full-round sediment core samples for interstitial water analyses were collected every second or third core of sediment. The sediment was extruded from the core liner, the outer layer of the sediment was removed by scrapping with a spatula, and the sample was placed in a Carver Laboratory Hydraulic Press for removal of interstitial water. The press was operated to a pressure of about $30,000 \mathrm{psi}\left(2.11 \times 10^{7} \mathrm{~kg} / \mathrm{m}^{2}\right)$. The sediment sample remained under pressure until water could no longer be squeezed from it. Interstitial water was collected in $50-\mathrm{cm}^{3}$ syringes and filtered through a $0.45-\mu \mathrm{m}$ Millipore filter. IAPSO standard seawater was the primary standard for the water analysis onboard ship.

Individual inorganic parameters were analyzed according to procedures outlined by Gieskes and Peretsman (1986). Alkalinity and $\mathrm{pH}$ were determined by using a Brinkmann- $650 \mathrm{pH}$ meter coupled with a Brinkmann-655 Dosimat. The $\mathrm{pH}$ value of the sample was calibrated with $4.01,6.86$, and 7.41 buffer standards; readings in millivolts were converted to $\mathrm{pH}$. The $\mathrm{pH}$ measurements were made immediately prior to the alkalinity measurements. The 3 - to $5-\mathrm{cm}^{3}$ interstitial water sample, after being tested for $\mathrm{pH}$, was titrated with $0.1 \mathrm{M} \mathrm{HCl}$ as a potentiometric titration (Gieskes, 1973).

Salinity was determined by means of a hand-held AO refractometer that measures the total dissolved solids. Sayles et al. (1970) found that this "salinity" agreed well with their measured ion sums.

Chlorinity was determined by titrating $0.1 \mathrm{~mL}$ of sample, diluted with $5 \mathrm{~mL}$ of deionized water, with silver nitrate. The 
Mohr titration used potassium chromate as an indicator. In addition, electrometric titrations were carried out. The electrometric technique utilized potentiometric titration with $\mathrm{Ag} / \mathrm{Ag} 25$ coupled electrodes. The Gram method was used to evaluate the equivalence volume (Jagner and Aren, 1970). Accurate results to within about $0.5 \%$ of the IAPSO seawater standard were obtained with this method.

Sulfate was quantified using a Dionex-2120 Ion Chromatograph. Calcium was determined by complexometric titration of a $0.5-\mathrm{cm}^{3}$ sample with EGTA using GHA as an indicator. To enhance the determination of the endpoint, the calcium-GHA complex was extracted into a layer of butanol (Gieskes, 1973). No correction was made for strontium, which is also included in the result.

Magnesium was determined by EDTA titration for total alkaline earths (Gieskes, 1973). Subsequent subtraction of the calcium value (also including strontium) yielded the magnesium concentration in the interstitial water sample. Ammonia and silica determinations were carried out using colorimetric methods described by Gieskes and Peretsman (1986).

\section{PHYSICAL PROPERTIES}

\section{Introduction}

Physical property measurements of sediments recovered during deep sea coring operations provide an important link between geophysical data, such as marine seismic survey records or electric well logs, and the geological realities of the materials that constitute the sedimentary section described by shipboard stratigraphers and sedimentologists. It is the combination of these three data sets that allow for a broader and more reasonable view of the seafloor around the borehole. The goal of the physical properties program during Leg 110 , beyond aiding in geophysical interpretation, was to attempt to quantify the changes which different sedimentary units have undergone as a result of their involvement in the tectonic processes associated with an active accretionary prism.

\section{Index Properties}

\section{Methods}

Index properties measured during ODP Leg 110 include water content, porosity, bulk density, and grain density. Bulk density and porosity are listed in the PHYSICAL PROPERTIES column on core description sheets (Fig. 10). The water content values in this volume are reported in two ways: (1) weight of water relative to the weight of dry solids (used in text), and (2) weight of water relative to the total wet sample weight. Weights were obtained using a programmed dual ScienTech pan system with an estimated error of $\pm 0.03 \mathrm{~g}$. Volumetric measurements were obtained by using a helium-purged Quantachrome pycnometer with an estimated error of $\pm 0.02 \mathrm{~cm}^{3}$ (multiple measurements) or $\pm 0.05 \mathrm{~cm}^{3}$ (single measurement; used at Site 671 ). All index properties reported herein are corrected for salt assuming a pore-water salinity of $35 \%$. Further details of calculations can be found in Boyce (1976). Samples were freeze dried for a minimum of $12 \mathrm{hr}$, weighed, volume remeasured, and then split for carbonate (coulometrics) and bulk mineralogy (XRD) analyses.

Bulk densities and porosities were also obtained from GRAPE (gamma-ray attenuation porosity evaluation) scanning of wholeround core sections. Bulk densities and porosities are computed assuming a grain density of $2.75 \mathrm{~g} / \mathrm{cm}^{3}$. Further details of this analytical tool are discussed by Boyce (1976). The reader is advised to exercise caution when using GRAPE data from cores obtained using the extended core barrel (XCB). Biscuiting, a common core-disturbance feature, produces interlayering of in- tact 'biscuits' and drilling slough or breccia. Peak values of GRAPE porosities and densities, associated with intact biscuits, are used in the following discussions.

\section{Compressional Wave Velocity}

\section{Methods}

Sonic velocities $\left(V_{p}\right)$ of sediments in the recovered core were measured using two different techniques. A continuous measurement of $V_{p}$ was made through the whole core using a $V_{p}$ Logger. The $V_{p}$ Logger employs two $1-\mathrm{MHz}$ transducers which are pressed against the side of the core liner as it passes between them on a belt-driven track. The distance between the acoustic transducers is measured by a pair of displacement transducers affixed to the measuring surfaces. Travel time is calculated from the full-waveform signal by an automatic peak-picking routine on a dedicated microcomputer and corrections for the thickness and delay time of the liner are employed to arrive at the velocity of the material in the core liner. As with the GRAPE scan, this method is most effective when core sections are totally filled with undisturbed material, such as during advanced piston corer (APC) operations. Core disturbance, biscuiting, and undergage core (or voids) severely degrade the data. An example of a $V_{p}$ Logger record for an APC core is shown in Figure 15.

$V_{p}$ was measured in two directions, horizontal propagation (normal to the axis of the core) and vertical propagation (parallel to the axis of the core) on discrete samples. In intervals of severe core disturbance, measurements were made only on competent "biscuits" or were not made at all. The Hamilton Frame

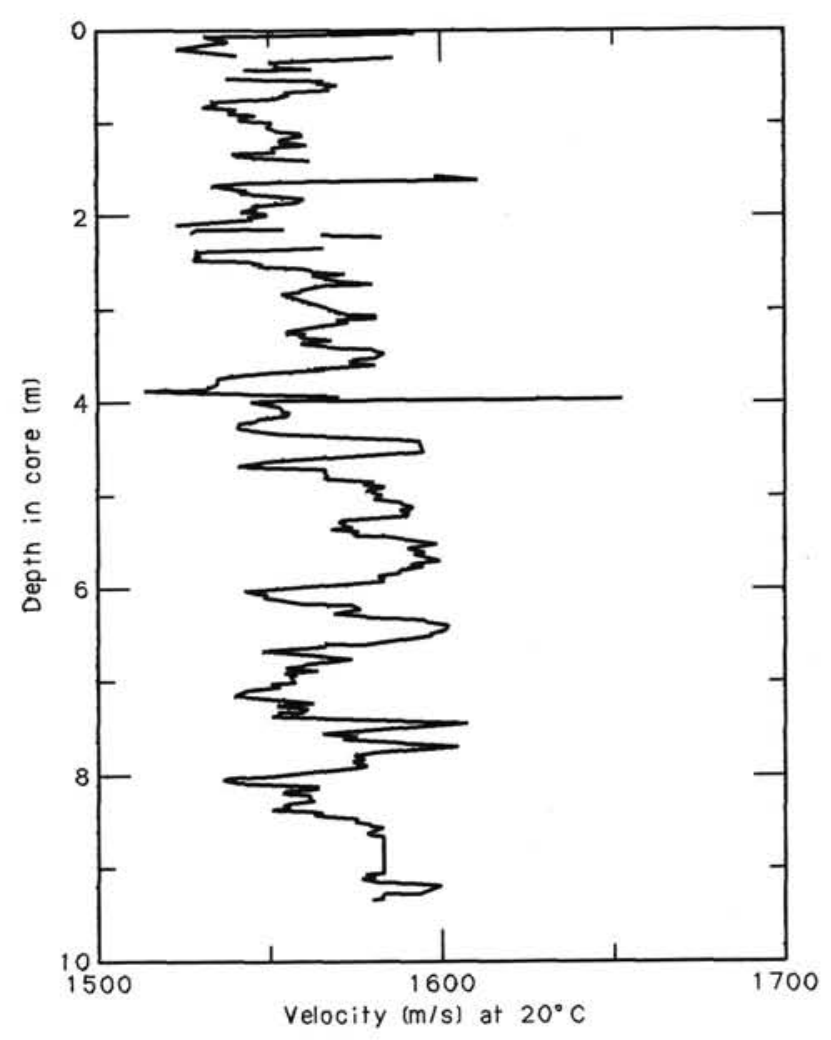

Figure 15. Compressional wave velocity of Core 110-671B-9H, continuously measured through the core liner by the $P$-wave logger. Depth interval is 73.9 to 83.4 mbsf. Major excursions correspond to either voids at the end of core sections or brass slugs placed at the end of each section to indicate the end of data. 
Velocimeter was used for velocity determinations, and the procedures followed were generally those of Boyce (1976a) with the addition of an automatic timing circuit provided by the ODP. Lucite and aluminum standards were run prior to drilling and the timing mechanism was found to be accurate to within $1 \%$ when adequate signal strength was achieved. Signal strength criteria were employed during actual measurements to determine whether sample disturbance in the core precluded accurate velocity measurement.

\section{Formation Factor}

\section{Methods}

Formation factor is a measurement of the ratio of the electrical resistivity of an interval of core to the electrical resistivity of the sediment pore fluid. Studies of sedimentary rocks in the petroleum industry indicate that this value is relatively constant within a wide range of pore fluid resistivities. Use of the formation factor rather than the actual resistivity value of a sediment allows a better comparison of electrical properties of samples from differing environments where pore-fluid characteristics vary.

The use of formation factor measurements in marine sediments and the basic methodology employed during Leg 110 are discussed in Manheim and Waterman (1974). The measurement is made on intervals of split core using four in-line electrodes spaced $1 \mathrm{~cm}$ apart. These are inserted into the sediment. The outer two electrodes establish an electrical potential (in this case approximately $8 \mathrm{~V} \mathrm{AC}$ at $1000 \mathrm{~Hz}$ ) and the inner two electrodes measure a drop in potential that is proportional to the sediment resistivity. This value is then normalized using a similar measurement made in a seawater bath with the same geometry as a half core liner. The assumption that seawater and porewater are essentially the same is valid in most cases; however, corrections to formation factor values can be made on the basis of the porewater chemistry at a later date. Measurements are made on thermally equilibrated sections of core allowing the effects of temperature on the pore-fluid resistivity to be compensated by the seawater bath also being at room temperature.

\section{Shear Strength}

\section{Methods}

The undrained shear strength of the sediment was determined using the Ocean Drilling Program motorized miniature vane shear device following the procedures of Boyce (1976). The ODP device has a variable rate motor that was set to 56 degrees per minute. The instrument measures the torque and strain at the vane shaft using a torque transducer and potentiometer, respectively. Output for torque and strain are recorded on a HewlettPackard XY recorder in volts. The vane used for all measurements has a $1: 1$ blade ratio with a dimension of $1.27 \mathrm{~cm}$.

The shear strength reported is the peak strength determined from the torque vs. strain plot. In addition to the peak shear strength, the residual strength was determined from the torque vs. strain curve as the postpeak value in tests where the failure was not dominated by cracking of the sample (Pyle, 1984). An example of peak and residual strength determinations is shown in Figure 16.

Given the critical role that sediment strength has apparently played in the formation of the accretionary wedge, it is worthwhile at this point to highlight the nature and limitations of the undrained shear strength obtained from the minivane test. It is imperative to recognize that the undrained shear strength, whether measured by fall-cone, miniature lab or field vane, triaxial shear, shear box, unconfined compression, dilatometer, piezo-cone, or pressuremeter, is an artifact of the test procedure itself; the undrained shear strength of a sediment is not a

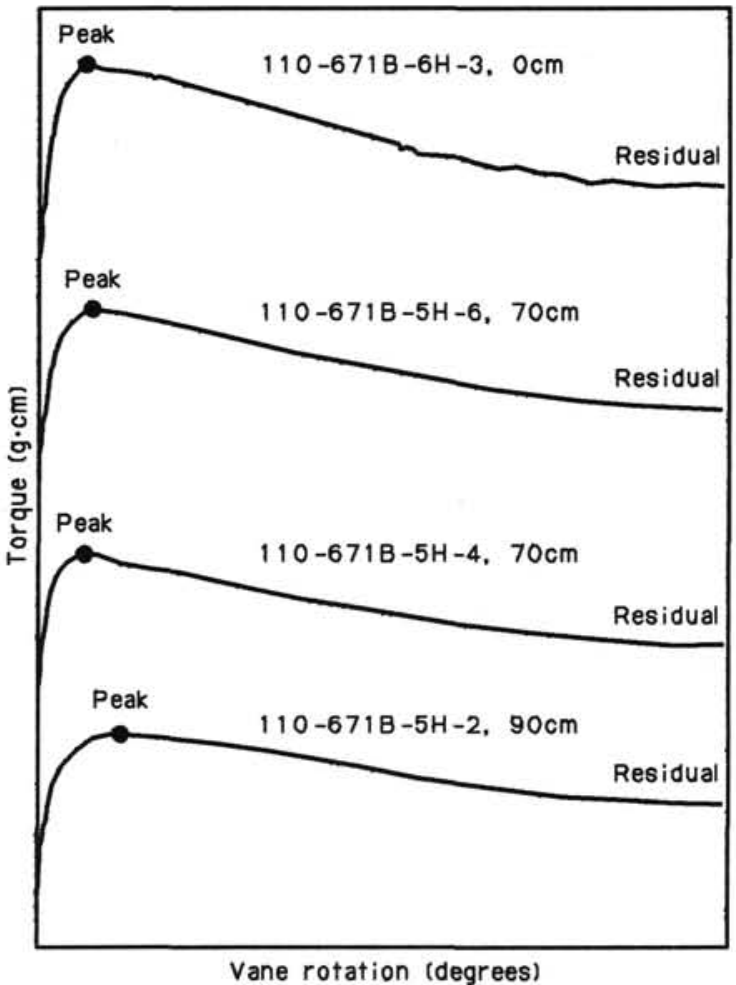

Figure 16. Curves of torque vs. strain showing the selection of peak and residual values of torque for strength determinations.

uniquely defined parameter. In fact, shear strength is a function of numerous factors, only a few of which are identical from one testing method to another. These include the following: the effective Mohr-Coulomb parameters-cohesion and the angle of internal friction (peak or residual); the effective normal stress (hence pore pressure); porosity or water content; strain magnitude; strain rate; confining stress level; temperature; loading path; the sample's stress history; composition; and the sediment's structural fabric. The undrained shear strength as measured by the minivane is not identical to the actual shearing resistance offered on potential planes of weakness within the sedimentary section. In a laboratory situation only properly controlled triaxial or simple shear tests at in situ stress conditions simulating appropriate stress paths can adequately represent the operative shear strength on potential slip surfaces.

The minivane test does, however, provide an estimate of strength and a means of comparing downcore and between-hole shear strength. In the analysis of vane tests the assumption is made that a cylinder of sediment is uniformly sheared about the axis of the vane in an undrained condition. Departures from this assumption include progressive cracking within and outside of the failing specimen, uplift of the failing core cylinder, drainage of local pore pressures (i.e., no longer the undrained condition), and stick-slip behavior. Incidents of all of the above have been observed in the testing of sediment on Leg 110 .

\section{Thermal Conductivity}

\section{Methods}

The thermal conductivity of the sediment was measured following the methods of Von Herzen and Maxwell (1959) using the needle-probe technique. Measurements were taken at locations on at least one, usually two, sections of each sediment core where GRAPE records indicated a homogeneous interval. 
Additional measurements were taken to bracket lithologies having significant density contrasts. Data were collected by inserting up to four needle probes through small holes drilled in the core liner. These probes are connected to a Thermcon- 85 unit mated to a Digital PRO-350 computer system. Software computes the coefficent of conductivity as a function of changes in resistance in the needles induced by changes in temperature over a 6-min interval. One probe is inserted in a rubber standard and run with each set of measurements. Temperature drift in the samples is calculated for each test series. A drift of less than 4 $\times 10^{-2}{ }^{\circ} \mathrm{C} / \mathrm{min}$ is essential for reliable data. This requires allowing cores to reach thermal equilibrium, which takes several hours, prior to determining conductivity.

\section{HEAT FLOW}

Temperatures were measured with two different tools on Leg 110 , the Von Herzen hydraulic piston corer temperature shoe (APC tool) and the water-sampler, temperature, and pore-pressure tool (WSTP tool) equipped with an Uyeda-type temperature probe (T-probe). Each of these instruments monitors the resistance of a single thermistor.

Temperatures recorded with the APC tool were extrapolated to equilibrium values following the procedure described by Koehler and Von Herzen (1986) and Horai and Von Herzen (1986). Temperatures measured with the T-probe were extrapolated to equilibrium using a method modified from Bullard (1954).

The two sediment-temperature instruments were calibrated during the early part of the cruise as follows: APC tools numbers 5 and 6 were first cross-calibrated by running them simultaneously in an ice-bath; the resulting difference in measured temperature was $<0.03^{\circ} \mathrm{C}$. Assuming APC tool 6 as a standard, a series of ice-bath and water-bath tests with this tool and the different T-probe thermistors were performed. All T-probe thermistors (tested without their electronics package) were within $0.03^{\circ} \mathrm{C}$ of APC tool 6 over a temperature range of 0 to $25^{\circ} \mathrm{C}$. However, when we compared APC and T-probe temperatures with the Tprobe electronics package in place, there was a significant difference in the recorded resistance from the previous calibration using no electronics package. T-probe thermistor 14 was found to have the most consistent response compared to APC 6 over the temperaure range. A linear resistance correction for the Tprobe thermistor/electronics package was added to the temperature reduction program for this tool. As a final test of the crosscalibration between instruments, the T-probe and APC-tools were made up in tandem and run into Hole 671B prior to circulation and logging.

Two different sampling intervals were used with the T-probe during measurements on Leg 110: $5.12 \mathrm{~s}$ with the new recorder and $60 \mathrm{~s}$ with the old one. Although these tools use different electronics packages, both use the same thermistor probes. The APC tool was run with variable recording intervals between 10 and $60 \mathrm{~s}$.

Thermal conductivity measurements are described under the Physical Properties section of this chapter.

\section{REFERENCES}

Bernard, B. B., Brooks, J. M., and Sackett, W. M., 1978. Light hydrocarbons in recent Texas continental shelf and slope sediments. $J$. Geophys. Res., 83:4053-4061.

Bernard, B. B., Brooks, J. M., and Sackett, W. M., 1976. Natural gas seepage in the Gulf of Mexico. Earth Planet. Sci. Lett., 31:48-54.

Bergen, J., 1984. Calcareous nannoplankton from Deep Sea Drilling Project Leg 78A: evidence for inbricate underthrusting at the Lesser Antillian active margin. In Biju-Duval, B., Moore, J. C., et al., Init. Repts. DSDP, 78A: Washington (U.S. Govt. Printing Office), 411445.

Biju-Duval, B., Caulet, J. P., Dufaure P., Mascle, A., Müller, C., Richert, J. P., and Valery, P., 1985. The terrigenous and pelagic series of Barbados island: Paleocene to middle Eocene slope deposits accreted to the Lesser Antilles margin. In Mascle, A. (Ed.), Symposium sur la geodynamique des Caraibes: Paris (Edition Technip).

Biju-Duval, B., Le Quellec, P., Mascle, A., Renard, V., and Valéry, P., 1982. Multibeam bathymetric survey and high resolution seismic investigations on the Barbados Ridge Complex (Eastern Caribbean): a key to the knowledge and interpretation of an accretionary wedge. Tectonophysics, 86:275-304.

Biju-Duval, B., Moore, J. C., et al., 1984. Init. Repts. DSDP, 78A: Washington (U.S. Govt. Printing Office).

Blanc, G., Boulegue, J., Badaut, D., and Stouff, P., 1986. Premier resultats de la campagne oceanographique hydrotherm (Mai 1985) du Marion-Dufresne sur la fosse Atlantis II (Mer Rouge). C. R. Acad. Sci. Paris, 302:175-180.

Bolli, H. M., Saunders, J. B., and Perch-Nielsen, K., (Eds.), 1985: Plankton stratigraphy. Cambridge, U.K. (Cambridge University Press).

Bouysse P., 1984. The Lesser Antilles island arc: structure and geodynamic evolution. In Biju-Duval, B., Moore, J. C., et al., Init. Repts. DSDP, 78A: Washington (U.S. Govt. Printing Office), 83-103.

Boyce, R. E., 1976. Definitions and laboratory techniques of compressional sound velocity parameters and wet-water content, wet-bulk density, and porosity parameters by gravimetric and gamma ray attenuation techniques. In Schlanger, S. O., Jackson, E. D., et al., Init. Repts. DSDP, 33: Washington (U.S. Govt. Printing Office), 931-958.

Boyce, R. E., 1977. Deep Sea Drilling Project procedures for shear strength measurements of clayey sediment using modified Wykeham Farrance laboratory vane apparatus. In Barker, P. F., Dalziel, I. W. D., et al., Init. Repts. DSDP, 36: Washington (U.S. Govt. Printing Office), 1059-1068.

Boynton, C. H., Westbrook, G. K., and Bott, M. H. P., 1979. A seismic refraction investigation of crustal structure beneath the Lesser Antilles island arc. Geophys. J. R. Astron. Soc., 58.

Bukry, D., 1973. Coccolith biostratigraphic zonation. In Edgar, N. T., Saunders, J. B., et al., Init. Repts. DSDP, 15: Washington (U.S. Govt. Printing Office), 685-703.

Bukry, D., 1975. Coccolith and silicoflagellate stratigraphy, northwestern Pacific Ocean, Deep Sea Drilling Project, Leg 32. In Larson, R. L., Moberly, R., et al., Init. Repts. DSDP, 32: Washington (U.S. Govt. Printing Office), 677-702.

Bullard, E. C., 1954. The flow to heat through the floor of the Atlantic Ocean. Proc. $R$. Soc. London, A222:408-429.

Cowan, D. S., Moore, J. C., Roeske, S. M., Lundberg, N., and Lucas, S. E., 1984. Structural features at the deformation front of the Barbados Ridge complex, Deep Sea Drilling Project Leg 78A. In BijuDuval, B., Moore, J. C., et al., Init. Repts. DSDP, 78A: Washington (U.S. Govt. Printing Office), 535-548.

Davis, D. M., and Hussong, D. M., 1984. Geothermal observations during Deep Sea Drilling Project Leg 78A. In Biju-Duval, B., Moore, J. C., et al., Init. Repts. DSDP, 78A: Washington (U.S. Govt. Printing Office), 593-598.

Davis, D., Suppe, J., and Dahlen, F. A., 1983. The mechanics of foldand-thrust belts. J. Geophys. Res., 88:1153-1172.

Dorel, J., 1981. Seismicity and seismic gap in the Lesser Antilles Arc and earthquake hazard in Guadeloupe. Geophys. J. R. Astron. Soc., 67:679-695.

Fontas, P., Valéry, P., Le Quellec, P., Mascle, A., Renard, V., Tardy, M., and Biju-Duval, B., 1985. Multibeam bathymetric survey of the Leg 78A drilling area and comparison with the southern part of the Barbados Ridge deformation front. In Biju-Duval, B., Moore, J. C., et al., Init. Repts. DSDP, 78A: Washington (U.S. Govt. Printing Office), 63-78.

Gealy, E. L., Winterer, E. L., and Moberly, R. M., Jr., 1971. Methods, conventions, and general observations. In Winterer, E. L., Riedel, W. R., et al., Init. Repts. DSDP, 7, Pt. 1: Washington (U.S. Govt. Printing Office, 9-26).

Gieskes, J. M., and Peretsman, G., 1986. Water-chemistry procedures aboard JOIDES Resolution-some comments. ODP Technical Note No. 5.

Gieskes, J. M., 1973. Interstitial water studies, Leg 15. Alkalinity, pH, $\mathrm{Mg}, \mathrm{Ca}, \mathrm{Si}, \mathrm{PO}_{4}$, and $\mathrm{NH}_{4}$. In Heezen, B. C., MacGregor, I. G., et al., Init. Repts. DSDP, 20: Washington (U.S. Govt. Printing Office), 813-829. 
Hay, W. W., 1970. Calcareous nannofossils from cores recovered on Leg 4. In Bader, R. G., Gerard, R. D., et al., Init. Repts. DSDP, 4: Washington (U.S. Govt. Printing Office), 455-501.

Horai, K., and Von Herzen, R. P., 1986. Measurement of heat flow on Leg 86 of the Deep Sea Drilling Project. In Heath, G., Burckle, L., et al., Init. Repts. DSDP, 86: Washington (U.S. Govt. Printing Office), 759-777.

Hubbert, M. K., and Rubey, W. W., 1959. Role of fluid pressure in the mechanics of overthrust faulting. I: Mechanics of fluid-filled porous solids and its application to overthrust faulting. Geol. Soc. Am. Bull., 70: 115-166.

Jagner, D., and Aren, K., 1970. A rapid automatic method for the determination of the total halide concentration in sea water by means of a potentiometric titration. Anal. Chim. Acta, 52:491.

Jordan, T. H., 1975. The present day motion of the Caribbean plate. J. Geophys. Res., 80:4433-4439.

Koehler, R., and Von Herzen, R., 1986. A miniature deep sea temperature data recorder: design, construction, and use. Tech. Rept. WHOI-86-3: Woods Hole (Woods Hole Oceanographic Institution).

Kulm, L. D., Suess, E., Moore, J. C., Carson, B., Lewis, B. T., Ritger, S. D., Kadko, D. C., Thornberg, T. M., Embley, R. W., Rugh, W. D., Massoth, G., J., Langseth, M. G., Cochran, G. R., and Scamman, R. L., 1986. Oregon subduction zone: venting, fauna and carbonates. Science, 231: 561-566.

LePichon, X., Toshimishi, I., Boulegue, J., Charvet, J., Faure, M., Kano, K., Lallemant, S., Okada, H., Rangin, C., Taira, A., Urabe, T., and Uyeda, S., in press. Nankai Trough and Zenisu Ridge: A deep-sea submersible survey. Earth Planet. Sci. Lett.

Manheim, F. T., and Sayles, F. L., 1974. Composition and origin of interstitial waters of marine sediments based on deep sea drill cores. In Goldberg, E. D., (Ed.), The Sea, 5: New York (Wiley-Interscience), 527-568.

Manheim, F. T., and Waterman, L. S., 1974. Diffusimetry (diffusion constant estimation) on sediment cores by resistivity probe. In Von der Borch, C. C., Sclater, J. G., et al., Init. Repts. DSDP, 22: Washington (U.S. Govt. Printing Office), 663-670.

Mascle, A., Cases, M., and Le Quellec P., 1985. Structure des marges et bassins Caraibes: une revue. In Mascle, A. (Ed.), Symposium sur la Geodynamique des Caraibes: Paris (Editions Technip).

Matthews, D. J., 1939. Tables of velocity of sound in pore water and in seawater: London (Admiralty, Hydrographic Dept).

Maury, R. C., and Westercamp, D., 1985. Variations chronologiques et spatiales des basaltes neogene des Petites Antilles; implication sur l'evolution de l'arc. In Mascle, A. (Ed.), Symposium sur la geodynamique des Caraibes: Paris (Editions Technip), 77-90.
Molnar, P., and Sykes, L. R., 1969. Tectonic of the Caribbean and Middle America regions from focal mechanisms and seismicity. Geol. Soc. Am. Bull., 80:1639-1684.

Müller, G., and Gastner, M., 1971. The "Karbonat-bombe," a simple device for determination of the carbonate content in sediments, soils and other materials. Neues. Jahrb. Mineral. Mh., 10: 466-469.

Ngokwey, K., Mascle, A., and Biju-Duval, B., 1984. Geophysical setting of Deep Sea Drilling Project, Site 541, 542, 543, Leg 78A, Barbados Accretionary Prism. In Biju-Duval, B., Moore, J. C., et al., Init. Repts. DSDP, 78: Washtington (U.S. Government Printing Office), 39-48.

Okada, H., and Bukry, D., 1980. Supplementary modification and introduction of code numbers to the low latitude coccolith biostratigraphic zonation (Bukry, 1973, 1975). Mar. Micropaleontology, 5: 321-325.

Pinet, B., Lajat, D., Le Quellec, P., and Bouysse, P., 1985. Structure of Aves Ridge and Grenada Basin from multichannel seismic data. In Mascle, A. (Ed.), Symposium sur la geodynamique des Caraibes: Paris (Editions Technip)., Paris, 53-54.

Pyle, M. R., 1984. Vane shear data on undrained residual strength. $J$. Tech. Div., Am. Soc. Civ. Eng., 110: 543-547.

Saunders J. P., 1979. Field guide to Trinidad, Tobago and Barbados. 4th Latin American geological congress, Port of Spain, Trinidad and Tobago.

Sayles, F. L., Manheim, F. T., and Chan, K. M., 1970. Interstitial water studies on small core samples, Leg 4. In Bader, R. G., Gerard, R. D., et al., Init Repts. DSDP, 4: Washington (U.S. Govt. Printing Office), 401-414.

Speed, R. C., 1981. Geology of Barbados: Implication for an accretionary origin. Oceanol. Acta, 4 (suppl.):259-265.

Sykes L. R., Mc Cann, W. R., and Kafka, A. L., 1982. Motion of the Caribbean plate during the last 7 million years and implication for earlier Cenozoic movements. J. Geophys. Res., 87:10656-10676.

Tomblin, J. F., 1975. The Lesser Antilles and Aves Ridge; In: Nairn, A., and Stehli, F. (Eds.), The Ocean Basins and Margins (Vol. 3): New York (Plenum Press), 1-64.

Von Herzen, R. P., and Maxwell, A. E., 1959. The measurement of thermal conductivity of deep-sea sediments by a needle probe method. J. Geophys. Res., 65: 1535-1541.

Wentworth, C. K., 1922. A scale of grade and class terms of clastic sediments. J. Geol., 30:377-390.

Westbrook, G. K., Mascle, A., and Biju-Duval, B., 1984. Geophysics and the sructure of the Lesser Antilles forearc. In Init. Repts. DSDP, 78A: Washington (U.S. Govt. Printing Office), 23-38.

Westercamp, D., 1979. Diversite, controle structural et origine du volcanisme recent dans l'arc insulaire des Petites Antilles. Bull. Bur. Rech. Geol. Min. IV:211-226.

Ms $110 \mathrm{~A}-102$ 